\title{
The role and impact of environmental class actions in Australia
}

\author{
Brooke Dellavedova* \\ Lawyer, Melbourne
}

Class actions provide a mechanism for grouping together like claims; and, in doing so, can enhance access to justice and the integrity of our democratic processes. Environmental class actions have an important role to play in environmental governance including by providing compensation and remediation, shaping norms of conduct and promoting accountability. There are, however, various limitations on the usefulness of class actions in achieving environmental objectives. In particular, the class actions regime is procedural rather than substantive (it does not overcome limitations on the availability or utility of causes of action for addressing environmental harm); it attracts the operation of additional rules and jurisprudence which may make some actions more difficult or not well suited to being brought as class actions; and class actions tend to be expensive and risky. Accordingly (and notwithstanding a recent flurry) we are unlikely to see the opening of the dreaded floodgates. Rather, environmental governance will most likely continue to be supported by the appropriate and considered commencement and conduct of meritorious actions.

Keywords: class actions, access to justice, environmental governance

\section{INTRODUCTION}

Class actions relating to environmental issues are not new, and there is unlikely to be a 'coming storm' of them. ${ }^{1}$ Given some recent developments in Australia, ${ }^{2}$ however, it is timely to consider their role and impact. This is important for several reasons. First, whilst Australia ranks poorly for its environmental performance, ${ }^{3}$ it has an evolved class actions regime which is attracting attention in connection with climate change litigation. ${ }^{4}$ Secondly, limited work has been performed regarding the impact

* The author thanks Professor Lee Godden, University of Melbourne, for providing feedback on an earlier draft, as well as an anonymous peer reviewer for feedback which was much appreciated. The author was previously a Principal of Maurice Blackburn Lawyers (which conducted some of the class actions referred to in this article) and in that capacity acted in the Murrindindi Bushfire and BHP class actions referred to.

1. Corey Byrne, 'Environmental Class Actions in Australia: A Coming Storm?' (2020) 37(2) Environmental \& Planning Law Journal 186.

2. Environmental class actions in other jurisdictions have been considered elsewhere, see, e.g. ibid, 192-5. This article focusses on Australia.

3. See, e.g., 'CCPI Countries and Rankings: Australia', Climate Change Performance Index (2021) <https://ccpi.org/country/aus/> accessed 5 July 2021; 'Australia', Climate Action Tracker (22 September 2020) <https://climateactiontracker.org/countries/australia/> accessed 5 July 2021.

4. See, e.g., Chris Merritt, 'Climate's Right for Class Actions', The Australian (29 March 2019); Kim Reid et al, 'A Growing Tide? Climate Change Proceedings Issued against the 
of environmental litigation, ${ }^{5}$ including class actions. Thirdly, environmental issues and class actions involve high stakes and are politically charged.

This article proposes a framework for balanced analysis of and engagement regarding the significance and impact of environmental class actions. It commences with a conceptual analysis of the role of environmental class actions, before moving to review significant actions and discuss their implications.

\subsection{The current 'moment' in environmental class actions}

Given that environmental harm may have widespread effects, it is unsurprising that class actions have been employed to seek redress. Whilst there has been a significant number of environmental class actions, ${ }^{6}$ they have not been comprehensively brought together for review. ${ }^{7}$ It is timely to do so, given increasing awareness regarding environmental issues, ${ }^{8}$ recognition of climate change risk as a corporate compliance and governance issue ${ }^{9}$ and interest in the use of litigation to achieve environmental objectives, ${ }^{10}$ as well as the incidence of 'next generation' ${ }^{11}$ environmental actions being brought in Australia and overseas. ${ }^{12}$

Federal Treasury', Allens Linklaters: Insight (12 August 2020) <www.allens.com.au/insightsnews/insights/2020/08/a-growing-tide-climate-change-proceedings-against-Federal-Treasury/> accessed 5 July 2021.

5. Joana Setzer and Rebecca Byrnes, Global Trends in Climate Change Litigation: 2020 Snapshot (Policy Report, Grantham Research Institute on Climate Change and the Environment and Centre for Climate Change Economics and Policy, London School of Economics and Political Science, 2020).

6. Cf Byrne (n 1) 197 noting that a narrower definition of 'environmental class actions' was adopted (187, fn 1).

7. See, however, Peter Cashman, 'Class Actions and Toxic Torts' (2005) 69 Precedent 4; Peter Briggs, John Taberner and Darren Bick, 'A Gold Mine for Environmental Class Actions in Australia?' (2010) 25(9-10) Australian Environment Review 8; Manisha Blencowe, Ben Hardwick and Hannah Lewis, 'Carving out the Role for Environmental Class Actions in Australia' (2018) 32(9-10) Australian Environment Review 237; Byrne (n 2).

8. See, e.g., discussion in Jacqueline Peel et al, Corporate Energy Transition: Legal Tools for Shifting Companies Towards Clean Energy Practices (University of Melbourne, September 2020) 5 [7].

9. See, e.g., Australian Securities and Investment Commission, '19-208MR ASIC Updates Guidance on Climate Change Related Disclosure' (media release, 12 August 2019) <https:// asic.gov.au/about-asic/news-centre/find-a-media-release/2019-releases/19-208mr-asic-updatesguidance-on-climate-change-related-disclosure> accessed 5 July 2021; Elisa de Wit and Kai Luck, 'The Emerging Threat of Climate-Related Litigation for Company Directors' (2020) 156 Precedent 45.

10. Jacqueline Peel, Hari Osofsky and Anita Foerster, 'Shaping the "Next Generation" of Climate Change Litigation in Australia' (2017) 41(2) Melbourne University Law Review 793, 799; Setzer and Byrnes (n 6) 3; Laura Schuijers and Margaret Young, 'Climate Change Litigation in Australia' in Climate Change Litigation: Global Perspectives (Brill Nijhoff, 2021).

11. This term has been used to refer to a 'next generation' of cases which seek to hold governments and corporations directly to account for the climate change implications of their actions, and which follow a 'first generation' of cases involving administrative challenge of proposed actions under environmental laws: Peel, Osofsky and Foerster (n 10) 793, 803.

12. In the Netherlands for example, an environmental group brought a successful class action against the State for orders that it pursue higher greenhouse gas emissions reductions targets: Urgenda Foundation $v$ State of the Netherlands ([2015] HAZA C/09/00456689); In the United 
Meanwhile class actions remain topical. ${ }^{13}$ Recent controversies have included whether there has been an 'explosion' of class actions, ${ }^{14}$ the role of commercial litigation funders; ${ }^{15}$ whether the courts can make orders for a 'common fund'; ${ }^{16}$ and whether lawyers conducting class actions for plaintiffs and group members can charge contingency fees. ${ }^{17}$

Attitudes to class actions generally span a continuum from those involving mass torts at the acceptable end, to commercially funded shareholder actions at the more maligned end. ${ }^{18}$ Environmental class actions appear to be well tolerated, ${ }^{19}$ but this could change if for example there is perceived to be a 'wave'20 or 'boom' ${ }^{21}$ of actions, or they are brought seeking damages for corporate non-disclosure (as seems likely to occur at some stage) and attract the complaints levelled at shareholder class actions. It is important therefore to critically examine environmental class actions having regard to their context and impact.

States, 21 children and an environmental organisation brought a class action against the United States government for climate-change related injuries, seeking declaratory and injunctive relief including requiring the government to implement a plan to phase out fossil fuel emissions, and draw down excessive carbon dioxide. The Court of Appeal recently they did not have standing, but rather 'the plaintiffs' impressive case for redress must be presented to the political branches of government': Juliana v United States 947 F.3d 1159, 1165.

13. See, e.g., Litigation Funding and the Regulation of the Class Action Industry (Commonwealth of Australia, 21 December 2020) <www.aph.gov.au/Parliamentary_Business/Commit tees/Joint/Corporations_and_Financial_Services/Litigationfunding/Report> accessed 5 July 2021.

14. See, e.g., Peter Cashman and Amelia Simpson, Class Actions and Litigation Funding Reform: The Rhetoric and the Reality (Supplementary Submission, Inquiry into Litigation Funding and the Regulation of the Class Action Industry, 16 July 2020) 23, 26-7, 29, 34, 38, 55; Vince Morabito, Shareholder Class Actions in Australia - Myths v Facts (Department of Business Law and Taxation Monash Business School Monash University, 11 November 2019).

15. For a discussion of the role and evolution of litigation funding see Byrne (n 1) 199-203.

16. Whereby the costs of the class action are shared by all group members if the case is successful, whether or not they have retained the lawyers conducting the action or entered into a litigation funding agreement with a funder. The High Court has found that courts do not have power to approve common fund orders, at least not pursuant to s 33ZF of the FCA Act or s 183 of the Civil Procedure Act 2005 (NSW). It may be open for a court to approve a CFO in the context of a settlment (in which s 33V is enlivened) or judgement: BMW Australia Ltd v Brewster (2019) 374 ALR 627; Davaria Pty Ltd v 7-Eleven Stores Pty Ltd (2020) 384 ALR 650.

17. Legal fees calculated as a percentage of any recovery, rather than legal costs incurred. The prospects of obtaining an order for contingency fees under Part IVA is uncertain: Impiombato $v$ BHP Billiton Ltd (No 2) [2018] ALR 162, [133]; Klemweb Nominees Pty Ltd (as trustee for Klemweb Superannuation Fund) v BHP Group Ltd (2019) 369 ALR 583, [22]-[23], [119], [139], [141]; both common fund orders and contingency fees are now explicitly permitted in grouped proceedings in Victoria following legislative amendment: Supreme Court Act 1986 (Vic) s 33ZDA.

18. See the summary of submissions to the Parliamentary Inquiry into Litigation Funding and the Regulation of the Class Action Industry in Cashman and Simpson (n 14) 29-38.

19. Submission, Inquiry into the Regulation of the Class Actions Regime (Australian Institute of Company Directors, 11 June 2020) 1 <https://aicd.companydirectors.com.au/-/media/cd2/ resources/advocacy/policy/pdf/2020/aicd-submission-inquiry-into-the-regulation-of-the-classactions-regime-11062020-002.ashx> accessed 5 July 2021.

20. Merritt (n 4).

21. de Wit and Luck (n 9) 47. 


\section{ENVIRONMENTAL CLASS ACTIONS}

Class actions provide a procedural mechanism for grouping together like or related claims so that they can be efficiently determined, and claims that might not otherwise be able to be brought can be brought. In doing so they provide a means for enhancing access to justice. ${ }^{22}$ Australia's mature federal regime ${ }^{23}$ is contained in Part IVA of the Federal Court of Australia Act 1974 ('Part IVA', 'FCA Act'), ${ }^{24}$ which enables a representative applicant to commence representative proceedings on behalf of group members in respect of similar or related claims which share a substantial common issue. ${ }^{25}$ Similar provisions exist in Victoria, ${ }^{26}$ New South Wales $^{27}$ and Queensland, ${ }^{28}$ and are being introduced in Western Australia. ${ }^{29}$ Before Part IVA was enacted, representative proceedings were brought relying upon earlier rules which required persons to have 'the same interest'. "Class actions' in this article refers to representative proceedings brought pursuant to any such provisions.

Important features of Part IVA include that the representative plaintiff must have a personal claim; ${ }^{31}$ only the representative plaintiff is liable for adverse costs (not group members) ${ }^{32}$ persons who fall within the defined class are group members ${ }^{33}$ unless they opt out; ${ }^{34}$ the Court may order that a proceeding not continue as representative

22. Commonwealth, Federal Court of Australia Amendment Amendment Bill 1991, House of Representatives, 14 November 1991, 3174 (Michael Duffy, Attorney General).

23. About which much has been written, see, e.g. Bernard Murphy and Camille Cameron, 'Access to Justice and the Evolution of Class Action Litigation in Australia' (2006) 30(2) Melbourne University Law Review 399; Vince Morabito, An Empirical Study of Australia's Class Action Regimes, Fifth Report: The First Twenty-Five Years of Class Actions in Australia (20 July 2017); Victorian Law Reform Commission, Access to Justice - Litigation Funding and Group Proceedings: Report (2018); Australian Law Reform Commission, Integrity, Fairness and Efficiency: An Inquiry into Class Action Proceedings and Third-Party Litigation Funders: Final Report (2018); Michael Legg and Samuel Hickey, 'Finality and Fairness in Australian Class Action Settlements' (2019) 41(2) Sydney Law Review 185.

24. Introduced by the Federal Court of Australia Amendment Act 1991 (Cth).

25. Federal Court of Australia Act 1976 (Cth) s 33C; for an overview of the provisions of Part IVA see: Legg and Hickey (n 23) 188-9; Maggie Doyle, 'The Nature of Representative or Class Actions in the Context of Compensation Claims Against Resources and Utilities Companies' [1999] AMPLA Yearbook 17, 282-93.

26. Pursuant to Part 4A, Supreme Court Act 1986 (n 17) introduced by the Courts and Tribunals Legislation (Miscellaneous Amendments) Act 2000 (Vic).

27. Pursuant to Part 10 of the Civil Procedure Act 2005 (NSW) introduced by the Courts and Crimes Legislation Further Amendment Bill 2010 (NSW).

28. Part 13A of the Civil Proceedings Act (2011) (Qld) introduced by the Limitation of Actions (Child Sexual Abuse) and Other Legislation Amendment Act 2016 (Qld).

29. Civil Procedure (Representative Proceedings) Bill 2019 (WA).

30. For a discussion of 'traditional' representative procedure regimes see Doyle (n 25) 278-81.

31. Federal Court of Australia Act (n 26) s 33D(1). Given that requirement and that the requirement of standing in PIL has been discussed elsewhere, it is not discussed further here. See, e.g. Michael Kirby, 'Deconstructing the Law's Hostility to Public Interest Litigation' (2011) 127 Law Quarterly Review 537, 538-43.

32. Federal Court of Australia Act (n 25) 43(1A); except where individual issues are agitated: s $33 \mathrm{R}(2)$.

33. Ibid, ss 33D(1), 33E.

34. Ibid, s 33J. 
proceeding where it is in the interests of justice to do so ${ }^{35}$ proceedings cannot be settled or discontinued without leave of the Court; ${ }^{36}$ and the Court can make any order it considers 'appropriate or necessary to ensure that justice is done in the proceeding'. ${ }^{37}$

The term 'environmental class action' is used in this article to mean any class action brought in respect of significant environmental harm or which has the purpose or effect of enhancing environmental governance. This includes actions which may not be brought pursuant to 'environmental' laws or regarded by the parties as being environmental cases - in other words class actions where environmental relevance may be 'incidental'. ${ }^{38}$ This approach may seem counter-intuitive in some respects. Bushfire survivors are not engaging in environmental activism when they seek compensation for example. However, it has been adopted for several reasons. First, it reflects the 'diverse assortment of laws that can have an influence concerning environmental problems'. ${ }^{39}$ Secondly, it reflects the complexity of environmental issues which may be 'invisible' when litigated, ${ }^{40}$ with the result that environmental litigation can happen inadvertently. ${ }^{41}$ For this reason it may be appropriate to think about class actions 'in the context of' the environment, rather than class actions 'about' or 'for' the environment. ${ }^{42}$ Thirdly, it focuses upon class action impact rather than intention. This is important because group members may have different views about the purpose of their action. Further, an holistic analysis of the impact of these actions may promote the effectiveness of strategic approaches and avoid them frustrating each other. ${ }^{43}$ Finally, it enables a range of environmentally relevant class actions to be brought together so that their role and impact can be considered.

\section{FRAMEWORK FOR ANALYSIS}

In considering the framework to apply to assess the impact of environmental class actions, regard should be had to the objectives and outcomes that might be sought to be achieved by those actions. At a deep level, this requires an inquiry into the 'societal goal' sought to be achieved by environmental law, ${ }^{44}$ and more broadly environmental governance. That inquiry is beyond the scope of this article; and, for present

35. Including because all the relief sought can be obtained by means of a proceeding other than a representative proceeding, or it is otherwise inappropriate that the claims be pursued by means of a representative proceeding: ibid, s $33 \mathrm{~N}$.

36. Ibid, s 33V.

37. Ibid, s 33ZF.

38. Setzer and Byrnes (n 5) 6-7.

39. Rob Fowler et al, The Foundations of Environmental Law: Goals, Objects, Principles and Norms (Technical Paper No 1, Australian Panel of Experts on Environmental Law) 2017, 10; Lee Godden, Jacqueline Peel and Jan McDonald, Environmental Law (2nd edn, Oxford University Press, 2018) 34 .

40. Kim Bouwer, 'The Unsexy Future of Climate Change Litigation' (2018) 30(3) Journal of Environmental Law 483, 502.

41. Ibid, 484.

42. Ibid.

43. Ibid, 494.

44. Fowler et al (n 39) 14. 
purposes, the role of the law in environmental governance is taken to be 'to facilitate social change by influencing the decisions and behaviour of individuals, governments, businesses, organisations and the community to embrace more sustainable forms of living'. ${ }^{45}$ More specifically, the purposes of environmental law are taken to be that: ${ }^{46}$

- 'it establishes the rights and responsibilities of governments and other key stakeholders in respect of the environment';

- 'it contributes to human well-being by ensuring that natural resources ... are used sustainably and thereby can continue to support economic development and meet social needs indefinitely ...';

- 'it safeguards nature's intrinsic values ... by protecting biodiversity and maintaining nature's life cycles and evolutionary processes';

- 'it protects important attributes of Australia's cultural heritage, history and national character'; and

- 'it allows individuals and communities to be involved in decisions that affect their environment, thereby contributing to the wider goal of democratising environmental management'.

Environmental democracy is a particularly pertinent objective, given the collective nature of class actions and their access to justice rationale, and the 'commons' nature of the environment, ${ }^{47}$ which we all bear a 'solemn responsibility' to protect. ${ }^{48}$ This 'commons' nature of the environment, and the trust-like basis upon which stewardship is granted or exercised mandates participation as something to be encouraged and taken up. ${ }^{49}$ The need for participatory democracy arises also for practical reasons. Environment challenges 'are ongoing, ubiquitous, and often unanticipated'. ${ }^{50}$ Private litigants may be more agile or willing than politicians or parliamentary processes in response to critical issues, and '[a]s in other countries, the moribund legislative and executive response to climate change [in Australia] has led to a shift in attention to the courts'. ${ }^{51}$ Participatory democracy may also counteract the scope for corruption in environmental decision making, ${ }^{52}$ and mitigate the risk of agency capture amongst statutory authorities that enforce environmental laws. ${ }^{53}$ Importantly, meaningful participation in environmental democracy requires procedural rights (such as class actions) which facilitate access to information and justice. $^{54}$

45. Godden, Peel and McDonald (n 39) 36.

46. Fowler et al (n 39) 11.

47. Bruce Lindsay and Hanna Jaireth, 'Australian Environmental Democracy and the Rule of Law - Thoughts from APEEL' (2016) 31(7) Australian Environment Review 245, 245.

48. United Nations Conference on the Human Environment, Report of the United National Conference on the Human Environment: Declaration of the United Nations Conference on the Human Environment (No UN Doc. A/Conf.48/14/Rev.1, 16 June 1972) Principle 1.

49. Bruce Lindsay, Hanna Jaireth and Nicola Rivers, Democracy and the Environment (Technical Paper No 8, Australian Panel of Experts on Environmental Law, 2017) 8.

50. Ibid, 6 .

51. Schuijers and Young (n 10) 49.

52. Lindsay, Jaireth and Rivers (n 49) 33.

53. Philip Alston, 'Representative Class Actions in Environmental Litigation' (1973) 9 Melbourne University Law Review 307, 308.

54. Lindsay, Jaireth and Rivers (n 49) 14 (citations omitted). 
In light of the above, it is contended that the impact of environmental class actions ought to be examined having regard to their contribution to achieving the purposes of environmental law (as an aspect of environmental governance); the access to justice and efficiency objectives of Part IVA; and the fundamental requirement for fairness and integrity in our civil justice system. ${ }^{55}$ Specifically, the following framework is proposed: ${ }^{56}$

- Access to justice - does the action provide access to remedies, establish rights and responsibilities and enforce the law for the public good, or promote accountability for wrongdoing?

- Environmental democracy - does the action promote access to information and participation regarding environmental issues?

- Environmental values - does the action contribute to the sustainable use of natural resources, safeguard nature or protect attributes of Australia's cultural heritage?

- Environmental governance - does the action facilitate social change by influencing decisions and behaviours in favour of environmental values?

- Integrity and fairness - has the action been commenced, managed, conducted and resolved in a way that promotes the integrity of our legal system and fairly balances the interests of parties?

- Efficiency - does the action provide a vehicle for resolving disputes more efficiently than had individual actions been brought?

\section{ACCESS TO JUSTICE}

Environmental class actions have on many occasions provided access to justice, including by assisting claimants impacted by significant environmental destruction to obtain compensation, determining the rights and responsibilities of the parties and holding wrongdoers to account. These actions span diverse kinds of environmental damage, industries, claimants and claims; and review demonstrates their significance for persons affected, utility in a wide range of circumstances and limitations. The following discussion considers examples of completed actions grouped by kind of damage, before discussing recurring themes relating to costs and funding, claims by foreign plaintiffs and substantive legal limitations.

55. The Australian Law Reform Commission's inquiry into class actions had regard to overarching principles including that '[i]t is essential to the rule of the law that citizens should be able to vindicate just claims through a process characterised by fairness and efficiency to all parties, that gives primacy to the interests of the litigants, without undue expense or delay', and that [t]he integrity of the civil justice system is essential to the operation of the rule of law': Australian Law Reform Commission (n 23) 16.

56. Within this framework, a relevant issue in environmental class actions is the recovery by claimants after deduction of legal costs and any funding commission. Given that this issue is and has been the subject of inquiry, and the limits of this article, it is not discussed here: ibid, 5; Litigation Funding and the Regulation of the Class Action Industry (n 13). 


\subsection{Contamination class actions}

In 1994 four Heads of Clans ${ }^{57}$ in Papua New Guinea brought a class action in Victoria ${ }^{58}$ on behalf of clan members against BHP (incorporated in Victoria) and its subsidiary Ok Tedi Mining Ltd ('Ok Tedi Class Action'). It was alleged the defendants had operated the Ok Tedi Copper Mine in Papua New Guinea without a tailings dam. ${ }^{59}$ The mine released ore-tailings and waste products straight into the Ok Tedi and Fly river systems, depositing sediment and copper particulates, killing fish, changing the course and flow of the river, impacting adjacent agriculture, destroying nearby ecosystems and devastating villagers. ${ }^{60}$

The action settled in 1996 on terms including that BHP would dredge the choked river and implement a feasible tailings option; ${ }^{61}$ and that a $\$ 110$ million compensation package would be made available for villagers, with those worst-affected also receiving at least $\$ 40$ million to help learn new skills. ${ }^{62}$ The settlement was regarded by some commentators as a triumph for environmentally sustainable development and a sign that western mining companies would be required to pay for their destructive activities in developing countries. ${ }^{63}$

In 2000 however proceedings were brought to enforce the settlement. It was alleged that the defendants had not implemented a tailings option, ${ }^{64}$ and tailings from the mine were still entering into the river systems. ${ }^{65}$ BHP argued that it was only required to implement a tailings solution as recommended by an inquiry after it had received necessary approvals from landowners, which had not happened, and the plaintiffs were precluded by their releases from bringing the enforcement proceedings. ${ }^{66}$ These enforcement proceedings settled in 2003, notwithstanding opposition from Papua New Guineans, ${ }^{67}$ and apparently on a basis that involved no further cost to

57. The first proceeding was brought by Rex Dagi in a representative capacity on behalf of himself and 24 other persons, all members of the Miripiki Clan (No 5782 of 1994); the second, by Barry John Shackles and Daru Fish Supplies Pty Ltd (No 5980 of 1994); the third by Baat Ambetu and 22 other persons, all members of the Yelan Marapka Clan (No 6861 of 1994); and the fourth by Alex Maun and 26 other persons, all members of the Marapka Clan (No 6862 of 1994): Dagi v BHP Ltd (Supreme Court of Victoria, Byrne J, 15 March 1995) 1.

58. Pursuant to sections 34 and 35 of the Supreme Court of Victoria Act 1986 (Vic), now superceded Dagi v BHP Pty Ltd (Supreme Court of Victoria, Byrne J, 10 November 1995) 21. 59. Jemima Garrett and Papua New Guinea, 'PNG's Ok Tedi: From Disaster to Dividends', ABC News (online, 7 January 2013) <www.abc.net.au/news/2013-01-07/an-radio-doco3a-oktedi/4455092> accessed 5 July 2021.

60. See, e.g., Stuart Kirsch, 'Is Ok Tedi a Precedent? Implications of the Lawsuit' in Ok Tedi Settlement Issues (n 63), 118, 99-101; Alex Maun, 'The Impact of the Ok Tedi Mine on the Yonggom People' in Ok Tedi Settlement Issues (n 63), 113-14; Kirsch 121-6.

61. Glenn Banks and Chris Ballard (eds), The Ok Tedi Settlement: Issues, Outcomes, and Implications (National Centre for Development Studies, Research School of Pacific Studies, Australian National University, 1997) 216 [5.2].

62. 'Ok Tedi - Entering Uncharted Territory', Slater and Gordon <www.slatergordon.com.au/ blog/featured/ok-tedi-entering-uncharted-territory> accessed 5 July 2021.

63. Colin Filer, 'West Side Story: The State's and Other Stakes in the Ok Tedi Mine' in $O k$ Tedi Settlement Issues (n 63) 56, 57.

64. Dagi v The Broken Hill Proprietary Company Ltd [2000] VSC 486, [3].

65. Ibid, [4].

66. Ibid, [6]-[7].

67. Stuart Kirsch, 'No Justice in Ok Tedi Settlement' (June 2004) Cultural Survival Quarterly Magazine <www.culturalsurvival.org/publications/cultural-survival-quarterly/no-justice-oktedi-settlement> accessed 5 July 2021. 
the BHP Group, and the plaintiffs acknowledging that the Group had complied with the 1996 settlement and no longer had a contingent liability in relation to Ok Tedi. ${ }^{68}$

Whilst the Ok Tedi Class Action enabled villagers to obtain compensation and an agreement regarding environmental remediation, the action illustrates that even 'successful' class actions do not necessarily resolve all of the issues between the parties, and are of no particular assistance in terms of enforcement.

In another contamination matter, plaintiffs commenced three class actions for land and business owners who claimed to have suffered loss caused by contamination by firefighting foam containing per- and poly-fluoroalkyl substances ('PFAS', 'PFAS Class Actions'). The Commonwealth used the foam at Royal Australian Air Force bases in Katherine (in the Northern Territory), and Oakey and Williamtown (New South Wales) over many years. The actions settled prior to the commencement of trial. ${ }^{69}$ The combined settlement sum was A $\$ 212.5$ million, representing a high proportion of recovery by group members of their alleged losses. ${ }^{70}$ Outside of the class actions, the Commonwealth had dragged its feet in respect of remediation, ${ }^{71}$ and failed to adopt a Government recommendation for a compensation scheme for land owners and businesses. ${ }^{72}$

In another action, claims were brought by an Indonesian seaweed farmer on behalf of group members who allege they suffered loss when an oil spill damaged marine ecosystems essential for their livelihoods ('Montara Class Action'). ${ }^{73}$ The spill occurred in 2009 in the Montara oil field operated by the defendant in the Timor Sea, due to earlier failures in the suspension of an oil well in the oil field. During the spill the Australian Maritime Safety Authority applied 184,000 litres of chemical dispersants to dissipate the hydrocarbons on the surface of the water. ${ }^{74}$ The plaintiff and group members allege that dispersants and hydrocarbons reached the island where the plaintiff lives and works, killed or destroyed seaweed cultivated by the plaintiff and group members and reduced their seaweed production. ${ }^{75}$ The plaintiff alleges the defendant owed him and group members a duty of care in respect of the operation and suspension of the oil well and that the respondent breached that duty of care, causing the spill and consequent loss and damage. ${ }^{76}$ The Court recently determined

68. BHP Billiton Limited Interim Report for the Half Year Ended 31 December 2003 (Interim Report, BHP Billiton Ltd, 19 February 2004) 22 <www.bhp.com/-/media/bhp/documents/ investors/reports/2004/agaapfinancials19february2004.pdf?la=en> accessed 5 July 2021.

69. Smith v Commonwealth of Australia (No 2) [2020] FCA 837.

70. Ibid, [64].

71. Inquiry into the Management of PFAS Contamination in and around Defence Bases (Joint Standing Committee on Foreign Affairs, Defence and Trade, Parliament of the Commonwealth of Australia, 2018) 38-41.

72. Ibid, 98 [4.62] recommendation 5; Whole of Australian Government Response to the Report of the Joint Standing Committee on Foreign Affairs, Defence and Trade Inquiry into the Management of per-and Polyfluoroalkyl Substances (PFAS) Contamination in and around Defence Bases (Department of Agriculture, Water and the Environment, 28 February 2020) 16; Chris McLennan, 'Just as It Was Settling Class Actions, the Federal Govt Quietly Said No to PFAS Compo', Katherine Times (online, 4 March 2020) <www.katherinetimes.com.au/story/ 6661814/just-as-it-was-settling-class-actions-the-federal-govt-quietly-said-no-to-pfas-compo/> accessed 5 July 2021.

73. Further Amended Statement of Claim in Sanda v PTTEP Australasia (Ashmore Cartier)

Pty Ltd (Federal Court of Australia, NSD1245/2016, 28 July 2017), [1].

74. Sanda v PTTEP Australasia (Ashmore Cartier) Pty Ltd (No 3) [2017] FCA 1272, [3].

75. Ibid, [6].

76. Ibid. 
that the defendant did owe a duty of care to group members in its operation of the oil well, ${ }^{77}$ and that its breach of that duty caused oil to reach certain areas in the Rote/ Kupang region of Indonesia including the plaintiff's village, ${ }^{78}$ causing or materially contributing to the 'quick and dramatic death and loss of local seaweed crops' ${ }^{79}$ At the time of writing, the Court is yet to make final orders. ${ }^{80}$ Subject to any application for leave to appeal once those orders are made, or any class-wide settlement of claims, group members' individual compensation claims remain to be determined.

Other examples of contamination class actions in which claimants gained access to compensation include an action by graziers and other cattle industry participants against chemical company ICI, regarding use of the pesticide 'Helix' on cotton, which when fed to cattle contaminated their meat, ${ }^{81}$ and an action by residents of a suburban Melbourne estate against their local council and others in respect of alleged damage to their property caused by the migration of carbon dioxide and methane from an adjacent former municipal landfill ('Landfill Gas Class Action', referred to again below). ${ }^{82}$ A class action in respect of alleged contamination following dredging of Gladstone Harbour in Queensland impacting the quantity and quality of commercial seafood species is yet to be determined. ${ }^{83}$

\subsection{Natural disasters}

Natural disasters cause widespread destruction and devastation, including loss of human life ${ }^{84}$ and property, destruction of cultural heritage areas, ${ }^{85}$ death of wildlife and vegetation, habitat destruction and loss of biodiversity. ${ }^{86}$ Climate change is expected to cause longer fire seasons with more extreme fire danger days, and an increase in heavy rainfall. ${ }^{87}$ Both are likely to increase pressure on significant assets

77. Sanda v PTTEP Australasia (Ashmore Cartier) Pty Ltd (No 7) [2021] FCA 237, [1040].

78. Ibid, [828], [829], [859].

79. Ibid, [1008]-[1010].

80. Ibid, [1171].

81. Classes of claimants that were sufficiently proximate and could establish a causal link between damage and loss which was reasonably foreseeable succeeded at a trial of common liability issues, and their individual damages claims were determined or settled: McMullin v ICI Australia Operations Pty Ltd [1997] FCA 1298; McMullin v ICI Australia Operations Pty Ltd [1998] FCA 1172.

82. Residents were evacuated due to a risk of asphyxiation and explosion, and upon return, found their homes required extensive remediation, monitoring and other works. Property owners sought compensation for loss of use and enjoyment of their properties and diminution in their value. A \$23.5m settlement was approved in 2011: Wheelahan v City of Casey [2011] VSC 215.

83. An overview of the circumstances giving rise to the action is provided in Murphy Operator v Gladstone Ports Corp (No 4) [2019] QSC 228, [4]-[5].

84. 2009 Victorian Bushfires Royal Commission Final Report - Summary (Parliament of Victoria, 2009 Victorian Bushfires Royal Commission, 2010) 4.

85. Victoria's Bushfire Emergency: Biodiversity Response and Recovery - Version 2 (The State of Victoria Department of Environment, Land, Water and Planning, August 2020) 13. 86. Ibid, 10-13, 15-47; Royal Commission into National Natural Disaster Arrangements Report (The Royal Commission into National Natural Disaster Arrangements, 28 October 2020) 594, 353-5 [16.2], [16.11]-[16.13].

87. Royal Commission into National Natural Disaster Arrangements Report (n 86) 58. 
and infrastructure (such as electricity networks and dams), and where defects or failures cause or exacerbate disasters, class actions may follow. ${ }^{88}$

Class actions brought in respect of bushfires, of which there have been many, are summarized in Schedule 1. ${ }^{89}$ Bushfires class actions typically follow fires breaking out in extreme weather conditions and allege the fire was caused by the negligence of those responsible for the construction or maintenance of electrical infrastructure. ${ }^{90}$ Claims are also often made in nuisance and for breach of statutory duty. ${ }^{91}$ As can be seen from Schedule 1, bushfires class actions have delivered very significant compensation to bushfire survivors, and have been the only successful environmental class actions to include personal injury claims. ${ }^{92}$

As regards flood events, in January 2011 the Brisbane River Basin experienced significant rainfall, culminating in the river and other tributaries breaking their banks, flooding areas of suburban Brisbane and causing extensive property damage. The operator of a retail store in the affected area brought a class action on behalf of approximately 6,870 group members who had entered into a funding agreement and: held an interest in land, and suffered loss or damage from the flooding, or had their use and enjoyment of that land interfered with by floodwater; and/or owned personal property that was situated on flooded land (Brisbane Flood Class Action). ${ }^{93}$ It was alleged that the defendants had failed to comply with their flood mitigation manual

88. Whilst overall the proportion of fires caused by electrical assets is low for example, during extreme weather conditions that proportion rises dramatically: 2009 Victorian Bushfires Royal Commission Final Report - Summary (n 84) 12.

89. For discussion regarding early individual proceedings brought alongside each in respect of bushfires see: Tim Tobin and Andrew Fraatz, 'Bushfire Class Actions' [2012] (109) Precedent 4; AA Tarr, 'Subrogation and the Ash Wednesday Bushfire Disaster Comment' (1987) 11(2) Adelaide Law Review 232; 'Class Actions', Maddens Lawyers <https://maddenslawyers.com. au/class-actions-2/> accessed 5 July 2021.

90. See, e.g., Matthews v AusNet Electricity Services Pty Ltd [2014] VSC 663, [75], [186]; Perry v Powercor Australia Ltd [2012] VSC 113, [2]; Mercieca v SPI Electricity Pty Ltd [2012] VSC 204, [7]-[8]; Ramsay v AusNet Electricity Services Pty Ltd [2016] VSC 725, [2]; Thomas v Powercor Australia Ltd [2011] VSC 614, [2]; Rowe v Ausnet Electricity Services Pty Ltd [2015] VSC 232, [5]-[7], [12]; Williams v Ausnet Electricity Services Pty Ltd [2017] VSC 474, [3]; Johnston v Endeavour Energy [2016] NSWSC 1132, [4]. [6]; Herridge v Electricity Networks Corporation (No 4) [2019] WASC 94, [2], [3], [7]-[10]; Eades v Endeavour Energy [2018] NSWSC 801, [2]-[10]; Kuhn v Infigent Energy Ltd (2017/00131194), Further Amended Statement of Claim (18 June 2018); Hawker v Powercor Australia Ltd [2019] VSC 521; Cardosa v SA Power Networks (CIV-20-000667), Notice of a Class Action; Lenehan v Powercor Australia Ltd (No 2) [2020] VSC 159, [14]; Francis v Powercor Australia Pty Ltd (SCI201801113), Amended Writ and Statement of Claim (Supreme Court of Victoria, 18 April 2019); Tobin and Fraatz (n 90).

91. See, e.g., Matthews v AusNet Electricity Services Pty Ltd (n 91) [225]-[232]; Perry v Powercor Australia Ltd (n 91) [2]; Ramsay v AusNet Electricity Services Pty Ltd (n 91) [11]; Williams v Ausnet Electricity Services Pty Ltd (n 91) [3].

92. Claims in respect of death or personal injury need to take account of statutory thresholds and caps which may prevent or reduce recovery, and such claims tend only to be included in class actions where the injuries are very significant, as tends to be the case in respect of bushfires. See summary of applicable provisions in Rebecca Gilsenan and Michael Legg, 'Australian Class Action Settlement Distribution Scheme Design - Deciding Who Gets What' (2019) 38(1) University of Queensland Law Journal 26, 22-23.

93. Rodriguez \& Sons Pty Ltd v Queensland Bulk Water Supply Authority trading as Seqwater (No 22) [2019] NSWSC 1657, Chapter 1, [17]-[18]. 
(in particular regarding the use of forecasts in conducting flood operations and the priority to be given to maintaining dam safety and avoiding urban flooding). This resulted in them needing to make large releases of water to ensure the Wivenhoe Dam did not fail, which significantly contributed to the flow of water during the height of the flooding. ${ }^{94}$ The claims were brought in nuisance, negligence and trespass against three defendants who employed four flood engineers that conducted flood operations over the relevant period. ${ }^{95}$

The Court delivered a judgment on common issues in November 2019, finding for the plaintiff and group members in negligence. ${ }^{96}$ A partial settlement subsequently reached with two of the defendants for $\mathrm{A} \$ 440$ million (50 percent of the estimated liability for losses claimed by group members) $)^{97}$ has been approved, ${ }^{98}$ and judgment is pending in the appeal by one of the defendants. ${ }^{99}$

\subsection{Consumer actions}

In 2020 the Federal Court approved a settlement of class actions brought regarding the 'Dieselgate' emissions scandal, ${ }^{100}$ whereby Volkswagen and certain subsidiaries manufactured and sold diesel vehicles fitted with a 'defeat device'. The device comprised hidden software which caused affected engines to emit significantly higher levels of nitrogen oxide on the road than in the testing environment, thus defeating emissions regulations. Nitrogen oxide is considered harmful to human health and the environment, and its emissions are closely monitored in most countries including Australia. ${ }^{101}$ Whilst VW promoted its vehicles as 'clean diesel' and environmentally friendly, ${ }^{102}$ diesel vehicles fitted with a 'defeat device' offer no climatic advantages over petrol vehicles. ${ }^{103}$

The class actions sought compensatory damages for diminution in the value of purchasers' vehicles, alleging defendants engaged in misleading and deceptive conduct (by representing the vehicles complied with the Australian Vehicle Emissions Standards when they did not), and the vehicles were not of acceptable quality and did not comply with safety standards. The actions settled before judgment was delivered on a common issues trial for between $\mathrm{A} \$ 87$ million and $\mathrm{A} \$ 127.1$ million, depending

94. Ibid, Chapter 1, [26].

95. The owner of the dams (Queensland Bulk Water Supply Authority trading as Seqwater); an entity contracted to provide flood management services to Seqwater (SunWater Ltd) and the State of Queensland: ibid, Chapter 1, [19]-[21].

96. Ibid, Chapter 1, [17]-[18].

97. 'Notice of Proposed Settlement' <www.mauriceblackburn.com.au/media/6071/21-03-09qld-floods-settlement-notice-as-distributed-and-published.pdf> accessed 5 July 2021.

98. Rodriguez \& Sons Pty Ltdv Queensland Bulk Water Supply Authority (t/as Seqwater) (No 28) [2021] NSWSC 467.

99. 'Queensland 2011 Floods Class Action / Maurice Blackburn' <www.mauriceblackburn. com.au/class-actions/current-class-actions/queensland-floods-class-action/> accessed 5 July 2021.

100. Cantor v Audi Australia Pty Ltd (No 5) [2020] FCA 637.

101. Ibid, [4].

102. See, e.g., Plea Agreement dated 11 January 2017 filed in United States of America $v$ Volkswagon AG (United States District Court, Eastern District of Michigan, No 16-CR20394) [30], [44]-[45].

103. Katsumasa Tanaka et al, 'Climate Effects of Non-Compliant Volkswagen Diesel Cars' (2018) 13 Environmental Research Letters 044020. 
upon the number of registrants for the settlement (the estimated average payment for each participating vehicle is A\$2,800), ${ }^{104}$ plus costs. ${ }^{105}$

It is clear from the foregoing examples that environmental class actions have played a very significant role in providing access to compensation and establishing rights and responsibilities. Several themes are worthy of further consideration.

\subsection{Legal costs}

A critical issue that arises in terms of access to justice is that of legal costs, both those of the plaintiff and group members, and those of the defendant if the action is unsuccessful.

As regards the plaintiff's costs, litigation generally, and class actions litigation in particular, is expensive. ${ }^{106}$ For this reason, plaintiffs almost always seek financial support, including by way of commercial litigation funding or a fee-deferral mechanism such as a contingency or conditional fee arrangement. ${ }^{107}$ The availability of such support is closely influenced by the assessed prospects of success and quantum of claims. This is probably why cases involving contamination and mass disasters have been the most common environmental class actions: because the underlying circumstances are likely to involve property damage or personal injury, and lend themselves to traditional common law claims for compensation from which costs can be recovered in the event of a successful outcome. The PFAS, Montara and Floods Class Actions are all examples of funded environmental class actions. Personal injuries claims, including bushfires class actions, are typically not funded by commercial litigation funders, ${ }^{108}$ but are brought on a 'no win, no fee' basis ${ }^{109}$ (and security for costs is not usually sought). ${ }^{110}$ Future actions may be brought on a contingency fee basis in Victoria. ${ }^{111}$

104. Cantor v Audi Australia Pty Ltd (No 5) (n 100) [25].

105. Ibid, [25], [153].

106. Peter Cashman and Amelia Simpson, 'Research Paper 5 - The Costs and Funding Commissions of Class Actions' [2020] University of New South Wales Law Research Series 87, 2-12.

107. For an overview of these financial arrangements (in the context of international arbitration), see Lisa Nieuwveld and Victoria Sahani, Third-Party Funding in International Arbitration (Kluwer Law International B.V., 2016) including Chapter 1 (Overview) and Chapter 4 (regarding Australia).

108. See, however, Matthews v SPI Electricity Pty Ltd (No 9) [2013] VSC 671, [4(a)], [131], [134]-[136] where it appears certain insurers had agreed to provide partial funding to the plaintiff's solicitors in respect of disbursements. A distinction was drawn between this situation, where insurers were seeking recovery of loss, and the provision of commercial funding by which the funder sought to make a profit.

109. Research conducted in 2016 regarding personal injury class actions showed that none had been funded by a commercial litigation funder, but a majority had been conducted by the plaintiff's solicitors on a 'no win, no fee' conditional fee basis: Vince Morabito and Jarrah Ekstein, 'Class Actions Filed for the Benefit of Vulnerable Persons - An Australian Study' (2016) 35(1) Civil Justice Quarterly 61, 87-8; Thomas v Powercor Australia Ltd (n 90) [29].

110. In one matter orders for security were sought, including orders approving a notice which would have probed the group members as to their willingness and ability to meet security. The application was refused: Eades v Endeavour Energy (n 120) [14]-[15]. In the Kilmore Class Action one of the defendants sought orders that insurer group members, or alternatively the plaintiff, provide security for disbursements. Again, the application was refused: Matthews $v$ SPI Electricity Pty Ltd (No 9) (n 108).

111. Supreme Court Act 1986 (n 17) s 33ZDA. 
Another (less common) option for plaintiffs to meet their cost liability may be philanthropic support. ${ }^{112}$ Whilst private funding including by environmental groups was considered 'a legitimate means of enabling less wealthy individuals or groups to gain access to the courts' during the inception of Part IVA, ${ }^{113}$ it will be interesting to see how courts would approach this form of funding, given close scrutiny may be applied to protect group members who will be bound by the outcome, ${ }^{114}$ and the legitimate interests of defendants including as to costs. Another option in future may be the availability of crowd funding. ${ }^{115}$

As regards the defendant's costs, in Australia, costs typically follow the event. ${ }^{116}$ The threat of sizeable adverse costs is a significant disincentive to commencing litigation, but may be managed through obtaining after-the-event insurance, or an indemnity from a commercial litigation funder, either of which will also assist in providing security for the defendant's costs should that be required. Another option may be to seek a maximum costs order. In McVeigh v Retail Employees Superannuation Pty Ltd, an individual climate change case, the plaintiff (unsuccessfully) sought a maximum costs order in the sum of $\mathrm{A} \$ 310,450$, being the amount of an indemnity proffered by environmental organization Friends of the Earth Australia Inc in the event of an adverse costs order. ${ }^{117}$

In enabling meritorious environmental class actions to be prosecuted (and resourced to succeed) litigation funding and fee-deferral mechanisms have played a critical role in enabling claimants to access our courts. The Court acknowledged this when approving the settlement of the PFAS Class Actions, noting that the proceedings were particularly complex, and that it 'strain[ed] credulity to think that claims of this complexity and attended by such potential expense could have been litigated to a conclusion without third party funding of some sort'. ${ }^{118}$ Any modifications to the fee support mix available in Australia ${ }^{119}$ need to be carefully considered having

112. At least one philanthropic foundation is providing financial assistance to the solicitor with carriage of the O'Donnell and Sharma Class Actions (although it is not apparent whether support has been provided in respect of those actions): Belinda Sommer, 'The Australian philanthropists spending big and fast to fight catastrophic climate change', $A B C$ (online, 30 March 2021) <www.abc.net.au/news/2020-11-18/spending-down-millions-climate-change-philanthropy/ 12880114> accessed 5 July 2021.

113. Grouped Proceedings in the Federal Court (Australian Law Reform Commission, 1988) 46, [318].

114. Victorian Law Reform Commission (n 23) 38-42, [2.140]-[2.165].

115. Evan Hamman, 'Save the Reef! Civic Crowdfunding and Public Interest Environmental Litigation' (2015) 15(1) Queensland University of Technology Law Review 159. See also the Grata Fund, an independent crowd-funded public interest litigation fund 'Grata Fund', Grata Fund <www.gratafund.org.au/> accessed 5 July 2021.

116. Rules of court or statutes confer a discretion to award costs upon Australian courts, see, e.g., Federal Court of Australia Act (n 25) s 43(2). The discretion must be exercised judicially (on principle), and the usual principle is that costs follow the event, that is, the unsuccessful litigant pays the costs of the successful litigant: Oshlack $v$ Richmond River Council (1998) 193 CLR 72, [65]-[68]; Gray v Richards (No 2) (2014) 315 ALR 1, [2] per by French CJ, Hayne, Bell, Gageler and Keane JJ.; The fact that proceedings may be characterised as 'public interest litigation' may be a factor which contributes to there being special circumstances which justify a departure from the usual rule: Oshlack $v$ Richmond River Council per Gaudron and Gummow JJ.

117. McVeigh v Retail Employees Superannuation Pty Ltd [2019] FCA 14.

118. Smith v Commonwealth of Australia (No 2) (n 69) [82].

119. For example following the Parliamentary Inquiry into litigaton funding: Parliament of Australia, Parliamentary Joint Committee on Corporations and Financial Services (n 13). 
regard to any impact on access to justice, including by means of environmental class actions.

A final point in the context of costs and access to justice (and specifically enforcement of the law for the public good) is the scope for environmental class actions to be regarded as instances of public interest litigation (PIL). Importantly, where environmental class actions are so characterized, it may be appropriate that unsuccessful plaintiffs not be required to meet adverse costs. ${ }^{120}$ PIL typically refers to court proceedings brought by members of the public against the government or another public body to enforce or clarify the law for the public good. ${ }^{121}$ Environmental class actions are often brought against private entities, such as resource companies, and where they are brought against public bodies, as discussed below in the context of biosecurity cases, have not often succeeded. However, that is not a decisive factor in their characterization, ${ }^{122}$ nor is the fact they are often brought in respect of private claims. As has been noted for example, 'class actions for mass harms caused by pollution, although primarily concerned with the vindication of private rights, inevitably have the character of public interest litigation'. ${ }^{123}$ Rather, environmental class actions may be regarded as falling into the category of PIL 'where the interference with the public right is such that some private right ... is at the same time interfered with'. ${ }^{124}$ In any event it might be doubted whether environmental class actions involve 'only' private rights where public remedies (injunctions and declarations) are sought in to enforce public statues (such as the Corporations Act 2001), and as has been noted elsewhere, actions may soon be brought pursuant to new provisions of the Environment Protection Act 2017 (Vic) enabling 'eligible persons' to bring claims for compensation for contraventions of the Act (assuming they are adequately resourced to do so). ${ }^{125}$ The development of this line of argument may be another means by which the costs barrier can be addressed.

120. See, e.g., Oshlack v Richmond River Council (n 117) [45], per Gaudron and Gummow JJ, finding that the relevant statutory costs provision was not to be narrowly construed, and was 'applicable to new species of litigation and the discretion it confers is to be exercised so as to allow for the varied interests at stake in such litigation'; [119] per Kirby J, finding that a narrow view of the costs provision may have the effect of impeding or frustrating the achievement of public interest objectives for which standing was broadened.

121. Kirby (n 31) 537.

122. The Federal Court has found for example that a case against a superannuation trustee 'appears to raise a socially significant issue about the role of superannuation trusts and trustees in the current public controversy about climate change. It is legitimate to describe the Applicant's litigation as being of a public interest nature': McVeigh v Retail Employees Superannuation Pty Ltd (n 117) [9]. The Court however declined to make a maximum costs order where no evidence had been adduced that the proceeding would not continue without it, or as to the plaintiff's financial position or the environmental organisation's capacity to raise further funds: [14]-[16].

123. Byrne (n 1) 191.

124. Kirby (n 31) 539. Given the s 33C requirement, and that the issue of standing in the context of PIL has been explored extensively elsewhere including in the article referred to in this footnote, this issue is not explored further in the present article.

125. See Environment Protection Amendment Act (Vic) 2018, inserting new ss 309 and 313, scheduled to come into effect on 1 July 2021; Environment, 'Environment Protection Amendment Act 2018', Environment (25 May 2020) <www.environment.vic.gov.au/sustainability/ environment-protection-amendment-bill-2018> accessed 5 July 2021. Of particular interest may be the scope for contravention of various broad duties including the general environmental duty (GED) to give rise to damages claims: Environment Protection Act 2017 ss 25 (general 


\subsection{Environmental damage outside Australia}

Environmental damage is indifferent to jurisdictional boundaries, and circumstances arise where the alleged harm, the claimants and the defendants are in different or multiple jurisdictions. The difficulties of bringing environmental claims against foreign tortfeasors have been canvassed elsewhere. ${ }^{126}$ Two observations are made in this article, the first relating to environmental damage caused by Australian companies in foreign jurisdictions; the second relating to the scope for class actions to be centralized in one jurisdiction when conduct causes geographically widespread harm.

As regards actions in Australia, the Ok Tedi and Montara Class Actions are both examples of plaintiffs and group members in a foreign jurisdiction seeking to hold an Australian company to account in an Australian court for alleged environmental damage caused overseas (with the Montara Class Action perhaps the first in respect of transboundary harm emanating from Australia). ${ }^{127}$ Another example is the shareholder class actions brought and subsequently consolidated against listed Australian mining company BHP in respect of a mining complex operated in Brazil ('BHP Class Action').

Shareholder class actions are a potential growth area for environmental class actions, as demonstrated by this case, and the O'Donnell Class Action discussed below. Typically, these actions are brought for contraventions of the continuous disclosure requirements of the Corporations Act $2001^{128}$ and ASX Listing Rules, ${ }^{129}$ and for engaging in misleading and deceptive conduct in contravention of the Australian Securities and Investments Commission Act $2001^{130}$ and Corporations Act. ${ }^{131}$ Shareholders seek compensation for any price inflation attributed to misrepresentation or non-disclosure contraventions and paid for shares during the relevant period. ${ }^{132}$

The BHP Class Action concerns events in November 2015 when the Fundão tailings dam, part of a larger iron ore mining complex in Brazil, collapsed, unleashing '[a]bout 43 million $\mathrm{m}^{3}$ of tailings ..., generating mud waves $10 \mathrm{~m}$ high, killing 19 people and causing irreversible environmental damage to hundreds of water-courses'. ${ }^{133}$ The collapse left hundreds of thousands of people without clean drinking water, wiped out swathes of forest in protected areas, destroyed areas of cultural heritage and caused significant loss of fauna and flora in an important area for biodiversity conservation. ${ }^{134}$

environmental duty), 31 (duty to take action to respond to harm caused by pollution incident), 32 (duty to notify EPA of notifiable incidents), 39 (duty to manage contaminated land), 40 (duty to notify the EPA of contaminated land); discussed in: Byrne (n 1) 204-6.

126. See, e.g., (n 2).

127. Tom Clark, 'The Montara Oil Spill Class Action: Crossing Borders and Extending Time', List G Barristers (December 2017) <www.listgbarristers.com.au/publications/the-montara-oilspill-class-action-crossing-borders-and-extending-time> accessed 5 July 2021.

128. See, e.g., Corporations Act 2001 (Cth) ('Corporations Act') s 674.

129. ASX, 'Listing Rules' (1 December 2019) r 3.1.

130. Australian Securities and Investments Commission Act 2001 (Cth) s 12DA.

131. Corporations Act (n 128) s 1041H.

132. For a discussion of loss issues arising in shareholder class actions see Corey Byrne and Michael Legg, 'Market-Based Causation after TPT Patrol Pty Ltd v Myer Holdings Ltd' (2020) 37 Company and Securities Law Journal 295.

133. Flávio Fonseca do Carmo et al, 'Fundão Tailings Dam Failures: The Environment Tragedy of the Largest Technological Disaster of Brazilian Mining in Global Context' (2017) 15(3) Perspectives in Ecology and Conservation 145, 146.

134. Ibid, $146-8$. 
BHP indirectly owned a 50 percent interest in the company which owned and operated the mining complex including the dam. ${ }^{135}$ Following announcements to the market in the days after the collapse, the price of BHP shares fell significantly. ${ }^{136}$

Claims are brought by persons who purchased shares during the relevant period in BHP Ltd on the Australian Stock Exchange ('ASX'); or in BHP Group Plc, a company registered in England and Wales, on the London Stock Exchange ('LSE') or the Johannesberg Stock Exchange ('JSE') (the price of which also fell following announcements regard the dam collapse); and suffered a loss. ${ }^{137}$ The ASX claims are in respect of loss suffered as a result of the share price being higher than it would have been but for the alleged contraventions. ${ }^{138}$ The LSE and JSE claims are brought on the basis that BHP Ltd and BHP Group Plc had a dual listed company structure and operated as a single economic entity; during the relevant period, the LSE and JSE markets for those shares were markets in which the price of those shares was influenced by material information concerning BHP that became publicly available, which it did, and/or by price movements of the BHP ASX shares; and the contraventions caused the price at which BHP LSE and JSE shares traded to be higher than their true value and/or the market price that would have prevailed but for the contraventions. ${ }^{139}$ Claims by purchasers on the LSE and JSE have been permitted to proceed, following an unsuccessful attempt by the defendant to strike them out and an unsuccessful appeal. ${ }^{140}$

The BHP Class Action is only one of several criminal and civil actions brought in various countries in respect of the dam collapse, ${ }^{141}$ and shows that companies whose operations result in grave environmental harm may face diverse actions in multiple jurisdictions seeking to hold them to account.

In light of the significant overseas presence of Australian resource companies, ${ }^{142}$ the availability of Part IVA and the relatively inclusive approach taken by Australian courts to the exercise of jurisdiction, ${ }^{143}$ Australian courts may see more class actions brought in respect of environmental damage occurring overseas. In respect of meritorious claims with a valid basis for Australian courts to exercise jurisdiction, the bringing of such claims may be broadly regarded as being consistent with and conducive to effective environmental governance. There remain significant limitations on bringing such claims (in addition to those relating to costs, and the ability of courts to control proceedings, discussed below), such as jurisdictional impediments to considering claims involving possessory rights to or over foreign land, ${ }^{144}$ the operation of choice

135. Impiombato v BHP Group Limited (No 2) [2020] FCA 1720 [5].

136. Ibid, [6].

137. Ibid, [3], [6].

138. Ibid, [8].

139. Ibid, [9]-[11].

140. Ibid; BHP Group Limited v Impiombato [2021] FCAFC 93.

141. Impiombato v BHP Group Ltd (2020) 143 ACSR 301, [8]-[9], [39]-[41], [73], [75]-[76], [84]-[88], [105]-[107], [113]-[114].

142. Byrne (n 1) 212 fn 272.

143. Ibid, 213-14; The Australian approach can be compared with the United States, where class actions commenced in 2009 in the United States District Court for the Western District of Pennsylvania (where the defendant was headquartered), seeking compensation for injuries alleged to have been caused by emissions from aluminium refineries operated by Alcoa of Australia Ltd in Western Australia, were dismissed on the basis of forum non conveniens: Auxer $v$ Alcoa [2010] Rep. FSupp2d; Auxer v Alcoa, Inc [2011] 406 FedAppx 600.

144. See (n 6). 
of law rules, ${ }^{145}$ and practical difficulties in giving notice in foreign countries. ${ }^{146}$ Accordingly, it needn't be feared that our courts will be overrun with such claims.

As regards the second observation, the prospect of centralizing claims in one jurisdiction when conduct causes geographically widespread harm may have some appeal in terms of efficiency, and consistency of decision making, as it would remove the need to prepare and deploy evidence about the same circumstances in multiple jurisdictions, and for multiple courts to grapple with issues such as jurisdiction over nonresident group members in opt-out proceedings ${ }^{147}$ (although presumably there would remain issues associated with the recognition and enforcement of any judgment in the home jurisdictions of claimants located outside the seat of the litigation). On the plaintiff side, the prospect of a single proceeding might be attractive to claimants with limited scope to bring claims in their own jurisdictions; and to those conducting or funding such actions on a contingency basis, for whom the prospect of offering 'world peace' to defendants in exchange for a commission on global or widespread damages may be the 'holy grail' of plaintiff law. On the defence side, on one view, defendants may find it preferable to face a single action rather than being attacked on multiple fronts around the world, facing 'the potential for prejudice ... by reason of the risk of re-agitation of the same issues in potential foreign proceedings' ${ }^{148}$ However, this arrangement could give rise to liability to pay compensation to claimants who would not be able to bring claims in their own jurisdictions, considerably increasing the damages bill and making the prospect very unappealing. In any event, attempts to group foreign claims in a single jurisdiction (typically in North America) have thus far failed due to compelling comity and sovereignty considerations. ${ }^{149}$

\subsection{Substantive merits}

As noted above, class action mechanisms are merely procedural, and are neutral as regards the availability of a cause of action giving rise to damages. That environmental class actions ultimately stand or fall on their substantive merits is illustrated by examining two attempts to bring biosecurity class actions in Australia, both of which were unsuccessful, largely due to failure to establish a duty of care.

In the 1990s, consumers of oysters grown (and contaminated with Hepatitis A) in Wallis Lake in New South Wales sued the Great Lakes Council, the State of New South Wales, and certain oyster producers seeking compensation for personal injuries (Great Lakes Class Action). It was alleged that the Council failed to take reasonable steps to minimize human faecal contamination of the lake, ${ }^{150}$ and that the State

145. Byrne (n 1) 214.

146. Ibid.

147. Rachael Mulheron, 'Asserting Personal Jurisdiction over Non-Resident Class Members: Comparative Insights for the United Kingdom' (2019) 15(3) Journal of Private International Law 445.

148. A concern expressed by BHP in the BHP Class Action: Impiombato v BHP Group Limited (No 2) (n 136) [128].

149. F Hoffmann-La Roche Ltd v Empagran SA (United States Court of Appeals for the District of Columbia Circuit, Breyer Justice, 14 June 2004); Peta Spender and Michael Tarlowski, 'Morrison v National Australia Bank Ltd: Adventures on the Barbary Coast: Morrison and Enforcement in a Globalised Securities Market' (2011) 35 Melbourne University Law Review 37.

150. Ryan v Great Lakes Council [1999] ASAL(Digest) 55, [292]. 
through its agencies failed to take operational steps that were reasonably open to it to minimize the risk of consumers contracting a viral infection from the oysters. ${ }^{151}$ At first instance, ${ }^{152}$ and on appeal, ${ }^{153}$ the plaintiff and group members were successful. However, the High Court found that neither the Council or the State were under a relevant duty of care, ${ }^{154}$ finding that the inaction of the kind alleged against the Council and the State fell into that area of essentially political decision-making where it is inappropriate for the judiciary to tread. ${ }^{155}$ The producers were found not to have breached their duties.

In 2010 a commercial abalone fisherman brought an action on behalf of himself and others involved in the commercial abalone fishing industry against the State of Victoria and an abalone farm, Southern Ocean Mariculture Ptd Ltd ('SOM'), in respect of a virus that infected abalone and abalone habitat in Victoria in 2006 ('Abalone Class Action'). The action alleged that SOM negligently permitted the virus to escape from its farm where it broke out, and the government failed to control the spread of the virus, for example by requiring SOM to stop permitting the flow of effluent discharge from the farm into wild abalone habitat. ${ }^{156}$ The plaintiff alleged breaches of duty by various personnel for whom the State of Victoria was alleged to be vicariously liable, and claimed damages for economic loss. Claims in negligence against SOM were settled, and an initial trial proceeded against the State of Victoria. ${ }^{157}$

The Court found that the alleged State tortfeasors did not owe the plaintiff a duty of care, due to the potential for conflict in duties owed to SOM (and other farmers) and others in the supply chain such as divers and processors; ${ }^{158}$ the indeterminacy of the class of persons to whom the duty would be owed; ${ }^{159}$ the scope for disproportionate liability on the part of the State relative to the fault of any of the tortfeasors in deciding how to balance the interests of different groups and whether or not to exercise relevant statutory powers; ${ }^{160}$ the quasi-legislative nature of the statutory powers imposed (and incongruity in those circumstances of imposing a common law duty); the lack of the requisite degree of control exercised by the alleged State tortfeasors and difficulties associated with imposing a duty based on a requirement to persuade or advise a third party to act. ${ }^{161}$ The Court also found there was no breach of duty by individual tortfeasors, ${ }^{162}$ and the plaintiff's case failed on causation because one 'could only speculate how and when the disease came into the wild'. ${ }^{163}$

The plaintiff appealed, then settled with the State ${ }^{164}$ on the basis that the plaintiff paid $A \$ 2.57$ million (from the settlement with SOM) ${ }^{165}$ in satisfaction of the

151. Ibid, [336].

152. Ryan v Great Lakes Council (n 150).

153. Graham Barclay Oysters Pty Ltd v Ryan (2000) 102 FCR 307.

154. Graham Barclay Oysters Pty Ltd v Ryan (2002) 211 CLR 540.

155. Ibid, [6].

156. Regent Holdings Pty Ltd v Victoria [2013] VSC 601, [39]-[41].

157. Regent Holdings Pty Ltd v Victoria [2015] VSC 422, [4]-[7].

158. Regent Holdings Pty Ltd v Victoria (n 156) [223].

159. Ibid, [224].

160. Ibid, [225].

161. Ibid, [223]-[233].

162. Ibid, [262], [273], [275].

163. Ibid, [279].

164. Regent Holdings Pty Ltd v Victoria (n 157) [9].

165. Ibid, [13], [27]. 
State's costs. ${ }^{166}$ Group members received nothing, ${ }^{167}$ the State only recovered some of its costs ${ }^{168}$ and the plaintiff's solicitors and litigation funder wrote off significant costs. ${ }^{169}$

These cases demonstrate that class actions including environmental class actions are complex and difficult, and are attended by considerable risk and uncertainty even when presumably the prospects of success were assessed as favourable at commencement. That uncertainty and risk are good reasons why environmental class actions are unlikely to be commenced lightly.

\section{ENVIRONMENTAL DEMOCRACY}

A recent class action brought by children relating to climate change demonstrates the scope for environmental class actions to enable participatory democracy (and also raises questions about their suitability in some circumstances for doing so, discussed further below).

In September 2020 eight children commenced a class action against the Minister for the Environment on behalf of all children born before the commencement of the proceeding who ordinarily reside in Australia or elsewhere ('Sharma Class Action'). ${ }^{170}$ The action relates to an application by Whitehaven Coal Ltd for approval to substantially increase the amount and rate of coal to be extracted from its mine in New South Wales (the proposed increase, referred to as the 'Extension Project', having been determined to be a 'controlled action' within the meaning of section 75(1) of the Environment Protection and Biodiversity Conservation Act 1999, 'EPBC Act'). The plaintiffs seek a declaration that the Minister owes them a duty in the exercise of the statutory power to take reasonable care not to harm them, and an injunction restraining the Minister from exercising power under the EPBC Act in a manner likely to harm them in breach of that duty. ${ }^{171}$

The Concise Statement pleads that unless the rate of increase of $\mathrm{CO}^{2}$ concentration flattens, the plaintiffs and group members are likely to suffer harm including mental or physical injury including ill-health or death, or economic loss, including from more, longer and more intense bushfires, floods and other extreme weather events; sea-level rise and increasing loss of non-human species and ecosystems. It is alleged that if the project goes ahead, the plaintiffs and group members are more likely to suffer those harms.

In May 2021 the Court handed down judgment, finding that the Minister did owe plaintiffs the asserted duty (insofar as it related to personal injury), ${ }^{172}$ but declining to award the injunction sought. In respect of duty, the Court focused upon the foreseeability of harm and the relationship between the Minister and the plaintiff children. As to foreseeability, the Court considered ' $[\mathrm{t}]$ hat the combustion of $33 \mathrm{Mt}$ of coal from

166. Ibid, [13], [24].

167. Ibid, [28].

168. Ibid, [44].

169. Ibid, [24].

170. Concise Statement in Sharma v Minister for the Environment (Federal Court of Australia, VID607/2020, 8 September 2020), [1].

171. Originating Application in Sharma v Minister for the Environment (Federal Court of Australia, VID607/2020, 8 September 2020).

172. Sharma v Minister for the Environment [2021] FCA 560, [148], [416]. 
the Extension Project will contribute to an increase in atmospheric $\mathrm{CO} 2$ is both obvious and foreseeable'; and that: ${ }^{173}$

a reasonable person in the Minister's position would foresee that, by reason of the effect of increased $\mathrm{CO} 2$ in the Earth's atmosphere and the consequential increase in global average surface temperature, each of the Children is exposed, through the occurrence of heatwaves or bushfires, to the risk of death or personal injury.

The Court further found that 'in the context of there being a real risk that even an infinitesimal increase in global average surface temperature may trigger a $4{ }^{\circ} \mathrm{C}$ Future World, the Minister's prospective contribution is not so insignificant as to deny a real risk of harm to the Children'. ${ }^{174}$

The judgment of the High Court in the Great Lakes Class Action referred to above, in which no duty was found to be owed, was distinguished with the Court focussing on the lack of control over the risk of danger in that case (compared with the Minister's control in this instance), as well as that the Great Lakes case involved a nonfeasance (failure to act) whereas this case concerned a positive exercise of a power which creates 'a real risk of harm'. ${ }^{175}$

As regards the injunction, the Court found that a reasonable apprehension of breach had not been demonstrated, because it could not be assumed that approval of the Extension Project would necessarily constitute a breach, in circumstances where a more 'nuanced' response from the Minister including something short of 'unconditional approval' may be available, a prospect that had not been explored or contested in the hearing. ${ }^{176}$ The Court noted that 'a well-advised and responsible Minister' would take notice of findings in its judgment, that 'it might be expected that the Minister will consider publishing a "proposed decision" inviting public comment' ${ }^{177}$

In July 2020 the Court declared that: ${ }^{178}$

The [Minister] has a duty to take reasonable care, in the exercise of her powers under s 130 and s 133 of the Environment Protection and Biodiversity Conservation Act 1999 (Cth) in respect of referral EPBC No. 2016/7649, to avoid causing personal injury or death to persons who were under 18 years of age and ordinarily resident in Australia at the time of the commencement of this proceeding arising from emissions of carbon dioxide into the Earth's atmosphere.

It also made orders requiring the Minister to pay the plaintiffs' costs, and for the action not to proceed as a representative proceeding in respect of persons under 18 years and not ordinarily resident in Australia (during the hearing, plaintiffs had confined their claims to Australian children, ${ }^{179}$ and the Court indicated it would hear from parties and consider whether any orders should be made as to whether the representative nature of the proceeding should be confined or continued, ${ }^{180}$ which issue is discussed further below). Shortly thereafter the Minister filed a notice of appeal. ${ }^{181}$

173. Ibid, [247], [248].

174. Ibid, [253].

175. Ibid, [261]-[269]; referring to Graham Barclay Oysters Pty Ltd v Ryan (n 156).

176. Sharma v Minister for the Environment (n 172) [501].

177. Ibid, [504], [506].

178. Sharma v Minister for the Environment (No 2) [2021] FCA 774.

179. Sharma v Minister for the Environment (n 172) [4].

180. Ibid, [516].

181. Notice of Appeal in Minister for the Environment (Commonwealth) v Anjali Sharma (Federal Court of Australia, VID389 of 2021, 16 July 2021). 
This action may be regarded as an Australian manifestation of the Juliana litigation, ${ }^{182}$ instances of which are being brought in jurisdictions around the world, ${ }^{183}$ save that it is brought in respect of a specific project rather than in respect of a general failure to limit fossil fuel impacts. Depending upon what the Minister does next, it may provide a powerful and influential contribution to the protection of Australia's environment. Quite apart from what the Minister does next, and the outcome of the appeal, the finding of a duty of care to avoid causing injury to children in deciding whether to approve the Extension Project has been heralded as ground-breaking, ${ }^{184}$ and demonstrates the utility of environmental litigation in enabling participatory environmental democracy and the determination of important responsibilities.

\section{ENVIRONMENTAL VALUES}

Environmental class actions face some significant limitations in terms of their contribution to environmental values.

In the first place, environmental class actions are most likely to be brought once damage has already occurred, and only in circumstances giving rise to compensable claims, thus limiting the scope of their effectiveness as regards environmental values. A good example is bushfires class actions, which tend only to be available where the circumstances give rise to a tortious claim ${ }^{185}$ (and which do not contribute to the recovery of ravaged fauna and flora). Another complication of those actions may be potential conflict between bushfire protection and conservation values. ${ }^{186}$ Bushfires class actions may contribute to pressure on decision makers to prioritize the protection of property and infrastructure (through vegetation clearing for example) over longer term cumulative impacts such as the protection of native vegetation, ${ }^{187}$

\section{Juliana $v$ United States (n 12).}

183. See, e.g., Ali v Federation of Pakistan (Supreme Court of Pakistan, 2016); La Rose v Her Majesty the Queen [2020] FC 1008, (Federal Court of Canada); Mui Coal Basin Local Community v Permanent Secretary Ministry of Energy (High Court of Kenya, Constitutional Petition No 305 OF 2012).

184. Michael Slezak and Penny Timms, 'Australian Teenagers' Climate Change Class Action Case Opens "Big Crack in the Wall", expert says', ABC News (online, 27 May 2021) <www. abc.net.au/news/2021-05-27/climate-class-action-teenagers-vickery-coal-mine-legal-precedent/ 100169398> accessed 5 July 2021; Naomi Neilson and Naomi Neilson, 'Major Landmark Decision a "Victory" for Young Climate Change Activists', LawyersWeekly (online, 30 May 2021) <www.lawyersweekly.com.au/biglaw/31492-major-landmark-decision-a-victory-foryoung-climate-change-activists> accessed 5 July 2021.

185. A successful class action against the government for inaction on climate change causing a bushfire seems unlikely: George Newhouse, 'I've Won Cases against the Government before. Here's Why I Doubt a Climate Change Class Action Would Succeed', The Conversation (online, 15 January 2020) <http://theconversation.com/ive-won-cases-against-the-governmentbefore-heres-why-i-doubt-a-climate-change-class-action-would-succeed-129707> accessed 5 July 2021.

186. Anita Foerster, Andrew Macintosh and Jan McDonald, 'Trade-Offs in Adaptation Planning: Protecting Public Interest Environmental Values' (2015) 27(3) Journal of Environmental Law 459; see also: Stuart Little, 'Exploring the Tensions between Bushfire Protection and Biodiversity Conservation in the New South Wales Planning System' (Doctor of Philosophy Thesis, Faculty of Law, Humanities and the Arts, University of Wollongong, 2017).

187. Foerster, Macintosh and McDonald, ibid, [464]. 
however it seems unlikely that class actions wield significant influence beyond the fact and impact of bushfires themselves.

Further, even when successful, environmental class actions do not always protect or repair the environment. After the Ok Tedi Class Action for example, the mine continued operating. According to BHP, which withdrew from the mine in 2002, transferring its stake to the PNG Sustainable Development Program Limited ('SDP'), a development fund intended to operate for the benefit of the people of Papua New Guinea, ${ }^{188}$ '[e]arly closure of the mine was unacceptable to the PNG Government and affected landowner communities because of the significant social and economic benefits derived from the mine's operations by the people of PNG' ${ }^{189}$ Instead, the SDP was intended to apply dividends from the mine's continued operations 'throughout the remaining 10 -year economic life of the mine and for up to 40 years following the mine's closure' to fund development opportunities. ${ }^{190}$ The withdrawal agreement also 'provided for permanent dredging of sediments from the Lower Ok Tedi (at a current cost of US\$35 million per year), or implementation of an approved superior alternative mitigation measure, for the life of the mine'. ${ }^{191}$ However the administration of funds held on trust for the benefit of affected Papua New Guineans continues to be controversial. ${ }^{192}$

In some instances, the interest in remediation is subjugated to the need for finality. In the Landfill Gas Class Action some group members objected to the settlement, expressing anger about 'the defendants' refusal to take responsibility for what has occurred and to keep them properly informed of what is going on' ${ }^{193}$ The Court noted:

[t]here remains uncertainly as to whether remediation works have been effective and the problem of gas migration from the landfill has been solved. ... However, a line has to be drawn in the sand at some point, at least for the purposes of determining the compensation payable in respect of civil liability. ${ }^{194}$

In addition to the fundamentally reactive nature of most litigation (except where injunctive relieve is sought as in the Sharma Class Action), the usefulness of environmental class actions tends to be limited by the subordination of environmental repair to other issues between the parties and difficulties with enforcement. As has been noted, 'while direct and indirect regulatory impacts can be observed among all types of climate litigation, questions about whether the outcomes of these cases actually help to address climate change in a meaningful way as yet remain unanswered'.

188. 'BHP Billiton Withdraws from Ok Tedi Copper Mine and Establishes Development Fund for Benefit of Papua New Guinea People', BHP <www.bhp.com/media-and-insights/ news-releases/2002/02/bhp-billiton-withdraws-from-ok-tedi-copper-mine-and-establishesdevelopment-fund-for-benefit-of-papua-new-guinea> accessed 5 July 2021.

189. Ibid.

190. Ibid.

191. Ibid.

192. Nick Toscano, 'PNG's Ok Tedi Mine Disaster Money Locked in New Legal Fight', The Sydney Morning Herald (online, 2 November 2019) <www.smh.com.au/business/companies/ png-s-ok-tedi-mine-disaster-money-locked-in-new-legal-fight-20191102-p536s7.html> accessed 5 July 2021; Ben Doherty, 'Australian Greg Sheppard's Law Firm Says Charges over PNG Mine Fund Are "Politically Motivated", The Guardian (online, 22 January 2021) <www. theguardian.com/world/2021/jan/22/australian-greg-sheppards-law-firm-says-charges-overpng-mine-fund-are-politically-motivated> accessed 5 July 2021.

193. Wheelahan v City of Casey (n 83) [5].

194. Ibid, [8]. 


\section{ENVIRONMENTAL GOVERNANCE}

Likewise, the role of environmental class actions in facilitating social change by influencing decisions and behaviours in favour of environmental values is not clear-cut.

Even when the circumstances giving rise to an environmental class action are followed by governmental or industry reform, the class action proceedings may or may not be a contributing factor. Following the Victorian Bushfires Royal Commission into the Black Saturday bushfires, government and electricity distributors invested in measures designed to reduce the risk of bushfires caused by electrical assets. ${ }^{195}$ Whilst litigation risk seems likely to be a factor in investment decisions regarding electrical infrastructure, those measures were no doubt strongly responsive to the fact of the bushfires and the findings of the Royal Commission. Likewise, following the outbreak the subject of the Abalone Class Action there were industry reforms aimed at reducing the introduction and spread of the virus, but these predated the outcome of the class action and presumably reflected direct concerns regarding the virus.

As regards corporate actors, impact is likewise difficult to measure. It is unclear for example to what extent the Ok Tedi Class Action helped to achieve remediation, or brought about change in the mining industry, noting that whilst the case has been credited with driving change, ${ }^{196}$ the BHP Class Action involves environmental damage associated with the company's mining operations in Brazil.

Perhaps the most forceful impact in terms of environmental governance occurs when there is an alignment of public and private regulatory proceedings. VW's epic greenwashing campaign, the subject of the VW Class Action, affected around 10.7 to 11.5 million vehicles worldwide, ${ }^{197}$ with VW reportedly paying $\$ 35$ billion in fines and settlements. ${ }^{198}$ Regulatory and private actions in Australia and elsewhere have surely provided an expensive and forceful reminder to VW and highly visible warning to others regarding the perils of green fraud.

A final observation in the context of governance relates to the important role played by insurers in environmental class actions, and particularly those involving bushfires, where insurers have appeared as defendants ${ }^{199}$ and group members, ${ }^{200}$

195. Following the Victorian Bushfires Royal Commission into the Black Saturday bushfires government and electricity distributors invested in measures designed to reduce the risk of bushfires caused by electrical assets: Land Department of Environment and Energy, 'Powerline Bushfire Safety Program, Reducing the Risk of Bushfires Caused by Powerlines', (online, 29 June 2021) <www.energy.vic.gov.au/safety-and-emergencies/powerline-bushfire-safety-program> accessed 5 July 2021. Whilst those measures were no doubt in response to the fact of the bushfires, and the findings of the Royal Commission, litigation risk may be a factor in investment decisions regarding electrical infrastructure.

196. Gavin Murray and Ian Williams, 'Implications for the Australian Minerals Industry: A Corporate Perspective' in Glenn Banks and Chris Ballard (eds), The Ok Tedi Settlement: Issues, Outcomes, and Implications (National Centre for Development Studies, Research School of Pacific Studies, Australian National University, 1997) 196, 200.

197. Cantor v Audi Australia Pty Ltd (No 5) (n 101) [1].

198. Geoff Colvin, 'Volkswagen Emissions Damages Are Still Rolling in 5 Years Later', Fortune (online, 7 October 2020) <https://fortune.com/2020/10/06/volkswagen-vw-emissionsscandal-damages/> accessed 5 July 2021.

199. Schmid v Skimming [2020] VSC 493, [3], [10]; Ritchie v Advanced Plumbing and Drains Pty Ltd [2019] NSWSC 1028, [66].

200. Herridge v Electricity Networks Corporation (No 4) (n 91) [24]; Schmid v Skimming ibid, [19]. 
including as intervenors and objectors on settlement approval, ${ }^{201}$ contradictors on the issue of costs, ${ }^{202}$ participants in a 'consultation committee', ${ }^{203}$ and potential deep pockets for security. ${ }^{204}$ Insurers have also been active in shaping the class actions jurisprudence. For example, in Johnston v Endeavour Energy insurers attempted to opt out over 500 of their insured ${ }^{205}$ and commence alternative proceedings on their behalf, but the Court held they did not have power to so without the specific authority of their insured. ${ }^{206}$ The limit of a defendant's insurance cover has been considered a relevant factor in approving settlement. ${ }^{207}$

Discussion of insurance in the context of mass disasters tends to focus on the importance of maintaining adequate general insurance cover, ${ }^{208}$ its affordability in the wake of increasing disaster-related pay-outs, ${ }^{209}$ the responsiveness and clarity of policies, ${ }^{210}$ the performance of insurers in meeting their claims responsibilities, ${ }^{211}$ and the scope for influencing individual level mitigation of loss through the pricing of premiums. $^{212}$ In the shareholder context, it focusses on the impact on directors' and officers' insurance premiums and availability of coverage. ${ }^{213}$

Given their involvement in and exposure to climate change and environmental class actions, insurers might be expected to be actively involved in influencing high-level mitigation and adaptation efforts. However there is limited visibility of this occurring in Australia. ${ }^{214}$ Insurers are likely to continue to play an important role (or variety of roles) in environmental class actions, and the scope for leveraging

201. Johnston v Endeavour Energy (n 90) [13]-[17], [26]-[32], [67]-[74], [83]-[85]; Lenehan $v$ Powercor Australia Ltd (No 2) (n 90) [4].

202. Williams v Ausnet Electricity Services Pty Ltd (n 90) [50], [97]-[114].

203. Matthews v SPI Electricity Pty Ltd (No 9) (n 108) [25].

204. Ibid.

205. As noted above, group members may elect to 'opt out' of the representative proceeding, with the result that they are no longer group members bound by the outcome of the proceeding, and may commence their own proceedings: Federal Court of Australia Act (n 25) s 33J. In this instance, insurers purposed to exercise their rights of subrogation to opt out their insured from class action proceedings, presumably because they considered it would be more advantageous to them to pursue those claims by way of separate proceedings rather than having their claims dealt with as part of the extant class action.

206. Johnston v Endeavour Energy (n 90) [261]-[272].

207. Schmid v Skimming (n 195) [39].

208. Royal Commission into National Natural Disaster Arrangements Report (n 86) 417-20 [20.8], [20.15]-[20.20].

209. Ibid, 417 [20.9]-[20.10], 420 [20.21].

210. Ibid, 421-2 [20.29]-[20.37].

211. Queensland Floods Commission of Inquiry Final Report (Queensland Floods Commission of Inquiry, March 2012) 294-325 <www.floodcommission.qld.gov.au/_data/assets/ pdf_file/0007/11698/QFCI-Final-Report-March-2012.pdf> accessed 5 July 2021; Treasury, Report on the Natural Disaster Insurance Review: Inquiry into Flood Insurance and Related Matters (Natural Disaster Insurance Review, the Australian Government the Treasury, 2011) 110-11 [14.12-14.17].

212. Royal Commission into National Natural Disaster Arrangements Report (n 86) 421 [20.26].

213. Australian Law Reform Commission (n 23) 281-4 [9.81]-[9.88]; 'Insurance Industry Calls for Reform of Class Action Laws', Class Action Reporter (1 September 2020).

214. The Insurance Council of Australia established a Climate Change Action Committee (which has an action plan with a mission 'To take action that will assist and support Australia's transition to a resilient and low carbon economy and continue to offer affordable and accessible 
that involvement to maximize benefits in terms of access to justice, environmental values and efficiency may be an area worthy of its own research and analysis.

\section{INTEGRITY AND FAIRNESS}

Class actions are very closely supervised by courts, and there exist important and effective safeguards to protect the courts and parties from abuse, ${ }^{215}$ over and above practical barriers and disincentives to their commencement including cost.

At the outset, poorly conceived claims or those unlikely to succeed are dispensed with promptly, including by summary dismissal or agreement. ${ }^{216}$ The class action brought against mining company Pasminco in respect of noxious fumes emitted by its smelters in Port Pirie, South Australia and Cockle Creek, New South Wales ('Pasminco Class Action') is illustrative. The representative plaintiff and group members sought an injunction and damages for injury to their health and diminution to the value of their property. It was alleged that the noxious emissions were a defective product supplied in trade or commerce in contravention of the Trade Practices Act 1974 ('TPA'). ${ }^{217}$ The Federal Court has original jurisdiction to hear claims brought under Commonwealth statute, ${ }^{218}$ and if the TPA claims had been found to be 'genuine' and 'non-colourable', it would also have had accrued jurisdiction to determine the negligence and nuisance claims. ${ }^{219}$ This would have given the plaintiff and group members access to a broader regime for representative proceedings than was available in New South Wales (at the time) or South Australia. The Court struck out the action, finding the federal claims were 'obviously doomed to fail', 'not genuine', 'colourable' and 'fabricated' to bring the common law claims within the Court's jurisdiction. ${ }^{220}$ It also took the unusual step of awarding costs on an indemnity basis ${ }^{221}$ against the plaintiff's solicitors, finding that where solicitors crafted untenable claims that were bound to fail in a bid for jurisdiction, ${ }^{222}$ they and not the parties should suffer the consequences.

Meanwhile, the plaintiff and group members had commenced proceedings in the Supreme Court of Victoria. The action was again struck out due to defects arising

insurance products in a climate changed future ...') but this no longer appears to be active: $\mathrm{Cli}$ mate Change Action <https://insurancecouncil.com.au/issues-in-focus/climate-change-action> accessed 5 July 2021.

215. Including opportunities for parties to seek orders striking out a defective pleading including because it fails to disclose a reasonable cause of action or is otherwise an abuse of the Court Federal Court Rules 2011 r 16.21; the ability to seek summary dismissal on similar grounds, or that a party has no reasonable prospect of success ibid, $\mathrm{r} 26.01$; requirements for lawyers to certify that they have a proper basis for the pleading ibid, $\mathrm{r} 16.01$; and the power to award costs Federal Court of Australia Act (n 26) s 43; typically awarded against an unsuccessful party: Laguillo v Haden Engineering Pty Ltd (1978) 1 NSWLR 306.

216. See, e.g., Hawker v Powercor Australia Ltd (n 90); Block v Powercor Australia Ltd [2019] VSC 15.

217. The predecessor to the Competition and Consumer Act 2010.

218. Judiciary Act 1903 (Cth) s 39B(1A)(c).

219. Cook v Pasminco Ltd (2000) 99 FCR 548, [12]-[13].

220. Ibid, [14].

221. For a discussion of indemnity costs and the usual rule that costs follow the event see Sekhon v Chandyoke [2018] VSC 327.

222. Cook v Pasminco Ltd (No 2) (2000) 107 FCR 44, [65]. 
from the attempt to combine claims in respect of separate smelters in South Australia and New South Wales operated by different combinations of corporate entities in one proceeding. ${ }^{223}$ The proceeding was dismissed and leave to bring fresh grouped proceedings by separate actions ${ }^{224}$ does not appear to have been exercised.

Pasminco apparently encouraged claimants to deal with it directly, ${ }^{225}$ before entering voluntary administration in September $2001 .^{226}$ Since then, the disastrous and long-standing environmental and health impacts of the smelters has been heavily documented. ${ }^{227}$

223. In particular, the Court was not satisfied that the claims of the representative plaintiffs were in respect of or arose out of the same similar or related circumstances, nor that the requirement (at the time) for every representative party and all group members to have claims against all defendants could be satisfied Cook v Pasminco Ltd [2000] VSC 534, [25], [28], [41]-[45], [50]-[52].

224. Ibid, [67].

225. It was reported at the time that Pasminco encouraged claimants to contact it directly, and that it had employed a professional claims company for that purpose: Damian Tomlinson and Kate Tilley, 'Pasminco Settles Coverage Dispute', Business Insurance (20 August 2000) $<$ www.businessinsurance.com/article/20000820/STORY/10002230/Pasminco-settles-coveragedispute> accessed 5 July 2021; 'Class-Action Looms Again for Pasminco', Australian Financial Review (online, 12 January 2001) <www.afr.com/politics/class-action-looms-again-for-pasminco20010112-k0e9l> accessed 5 July 2021. Whilst direct settlements may have benefitted some claimants, they would have raised red flags today, in particular as regards whether plaintiffs were disadvantaged by direct settlements, and on access to justice and efficiency grounds: Lenehan $v$ Powercor Australia Ltd (No 2) (n 90); Murphy and Cameron (n 22) 429-430. Direct settlements are less prevalent today, following caselaw developments regulating communications and settlement with group members: Courtney v Medtel Pty Ltd [2002] FCA 957 [62], [64]-[67], [69]. Direct settlement approaches were made in a bushfires class action, and found to be misleading and unfair: Lenehan v Powercor Australia Ltd (No 2) (n 90).

226. 'History', Pasminco Suject to Deed of Company Arrangement (2007) <www.pasminco. com.au/index.php> accessed 5 July 2021.

227. 'Pasminco Cockel Creek - History', Pasminco Suject to Deed of Company Arrangement (2007) <www.pasminco.com.au/index.php/pasminco-cockle-creek/history> accessed 5 July 2021; 'Lead Abatement Strategy' <www.pasminco.com.au/index.php/lead-abatement-strategy> accessed 5 July 2021; Edward Maynard, Ian Calder and Catherine Phipps, The Port Pirie Lead Implementation Program: Review of Progress and Consideration of Future Directions, (1984-1993) (Public and Environmental Health Service, South Australian Health Commission, 1993); 'Remediation Order' Letter from Environment Protection Authority, 1 July 2003 $<$ https://majorprojects.planningportal.nsw.gov.au/prweb/PRRestService/mp/01/getContent? AttachRef=MP06_0184\%2120190807T041238.021\%20GMT > accessed 5 July 2021; Tristan Edis, 'Climate Spectator: Pasminco's Port Pirie Parable', The Australian Business Review (online, 8 December 2012) <www.theaustralian.com.au/business/business-spectator/news-story/climatespectator-pasmincos-port-pirie-parable/df00b3ee14e636ff19a5ae5783527338> accessed 5 July 2021; 'Editorial: Pasminco Pollution Saga Remains Unresolved, as Cost Concerns Remain Unaddressed', Newcastle Herald (11 December 2019) <www.newcastleherald.com.au/story/6536180/ pasminco-pollution-saga-continues/> accessed 5 July 2021; Donna Page, 'Lake Macquarie Homeowners Left Counting the Cost of Pasminco's Lead Pollution', Newcastle Herald (online, 24 August 2019) <www.newcastleherald.com.au/story/6344600/revealed-families-add-100000to-mortgages-to-pay-for-industrial-pollution-clean-up> accessed 5 July 2021; 'Pasminco Smelter Site Purpose Only Half the Job', Newcastle Herald (online, 24 August 2019) <www.newcastle herald.com.au/story/6345948/smelter-polluted-but-the-residents-pay/> accessed 5 July 2021; Helen Gregory, 'Breakthrough at Boolaroo for Disposal of Lead Contaminated Soil', Newcastle Herald (online, 17 January 2020) <www.newcastleherald.com.au/story/6585354/breakthroughat-boolaroo-for-disposal-of-lead-contaminated-soil/> accessed 5 July 2021. 
The judgments in both jurisdictions demonstrate the ability of courts and defendants to efficiently remove (and punish) non-compliant actions. However, access to justice for worthy claimants may have been thwarted. Twenty years later it is difficult to know whether more effective actions could have been brought. Important changes have occurred since then, including clarification of the requirements relating to commonality where there are multiple respondents, ${ }^{228}$ and a greater emphasis on efficiency, as discussed below. In any event, it seems unlikely Pasminco had the funds to pay for the damage. The case shows that successful environmental class actions require a confluence of factors beyond the existence of worthy claims.

Given their difficulty and risk it is unlikely that Australia will become awash from a 'wave' of well-financed green class actions. ${ }^{229}$ There exist effective means for managing unmeritorious or vexatious claims, and as to the rest, what is required from an access to justice perspective is a 'screen' rather than 'closed' door, 'which will keep out the pests whilst allowing genuine litigants with arguable causes, invoking the rule of law, to engage and influence the legal process'. ${ }^{230}$

\section{EFFICIENCY}

It is assumed for the purposes of this article that the conduct of multiple common claims as a class action is prima facie more efficient than the individual conduct of those claims, and so environmental class actions on their face provide an efficient mechanism for grouping together like claims, subject to two limitations discussed here. The first relates to the conduct of multiple class actions in respect of the same subject matter, and the second relates to actions where it is not obvious that it was necessary or desirable for the matter to have been brought as a class action.

As regards the first issue, the commencement of multiple class actions in respect of the same matter is a phenomenon that courts have managed effectively including with respect to environmental class actions. The PFAS Class Actions, whilst conducted by two law firms, were managed together for at least part of the time. ${ }^{231}$ Whilst the actions concerned contamination across three different sites (but involving the same contaminant and defendants), the Court stated it would have preferred the proceedings to have been brought in one class action to further reduce costs, ${ }^{232}$ and there is now one class action being conducted in respect of a further seven bases, with orders made to facilitate the use of documents from the first class action. ${ }^{233}$ In the VW Class Action, five actions brought by two law firms were conducted in the same docket as related regulatory proceedings, ${ }^{234}$ enabling the Court to apply acquired technical knowledge in both. ${ }^{235}$

228. The Court finding that it was not a requirement that each applicant and group member have a claim against each respondent in Gray v Cash Converters International Ltd (2014) 100 ACSR 29, affirmed in Cash Converters International Ltd v Gray (2014) 223 FCR 139.

229. cf Merritt (n 4).

230. Kirby (n 31) 538.

231. See Order of Justice Jago in Smith $v$ Commonwealth of Australia (Federal Court of Australia, NSD 1908 of 2016, 9 October 2018).

232. Smith v Commonwealth of Australia (No 2) (n 70) [74].

233. Haswell $v$ Commonwealth of Australia [2020] FCA 915.

234. Australian Competition and Consumer Commission v Volkswagen AG [2019] FCA 2166. 235. See, e.g., the Court's use of an agreed, detailed Technical Document across proceedings, ibid, [23]. 
This might be contrasted with the Floods Class Action, which only resolved (partially thus far) after a trial that ran from December 2017 to March 2019. ${ }^{236}$ Given the Court's criticisms of the engineers' evidence ${ }^{237}$ and the conduct of the defence, ${ }^{238}$ and that similar issues were ventilated before a Commission of Inquiry, ${ }^{239}$ it is unfortunate that such significant costs and delay have had to be incurred to achieve an as yet incomplete resolution, suggesting there is work yet to be done in promoting efficiency.

Environmental class actions often take place alongside or following regulatory proceedings or commission of inquiry. Given the overlap in subject matter and substantial costs involved, an issue for future consideration may be the extent to which class actions and inquiries can be conducted alongside each other to maximize efficiency, acknowledging that opportunities for this may be limited by differing objectives and standards of proof.

As regards the second issue, it is relevant to have regard to two recent class actions brought seeking injunctive and declaratory relief only. The first is an action brought in July 2020 by a holder of exchange-trade Australian Government Bonds on behalf of other investors against the Commonwealth and others ('O'Donnell Class Action'). The plaintiff alleges that the Commonwealth breached 'a duty of utmost candour and honesty' to investors, and engaged in misleading and deceptive conduct by failing to disclose Australia's climate change risks in promoting and arranging for the trading of the bonds (and that other respondents breached provisions of the Public Governance, Performance and Accountability Act 2013 (Cth)). ${ }^{240}$ Specifically, it is alleged that climate change risks (including physical impacts of climate change, transition impacts such as stranded assets and legal action, and sovereign reputational risk), to which Australia is materially exposed, can have a material impact on a decision by an investor to invest in sovereign bonds and their value and performance, and ought to have been disclosed.

Climate risk disclosure is an area upon which financial regulators, governance bodies and the legal community have been focussing, ${ }^{241}$ with good cause. Disclosure of climate risk may impact upon company and investor decision-making in important

236. Rodriguez \& Sons Pty Ltd v Queensland Bulk Water Supply Authority Trading as Seqwater (No 22) (n 94) Chapter 1 [42].

237. Ibid, Chapter 1 [52].

238. Ibid, Chapter 1 [55].

239. In 2012 the Queensland Floods Commission of Inquiry released its final report into various matters arising out of flooding in Queensland in 2010 and 2011, including the operation of dams, finding non-compliance with the manual for the Wivenhoe Dam. Parts of the evidence and findings of the Commission were tendered in evidence in the class action, but most of the evidence and the report itself were not tendered and were not read by the Judge. Queensland Floods Commission of Inquiry Final Report (n 208) 504.

240. Statement of Claim in $O^{\prime}$ Donnell v Commonwealth (Federal Court of Australia, VID482/ 2020, 23 December 2020).

241. Australian Securities and Investment Commission (n 9); Climate Risk Disclosure by Australia's Listed Companies, Report 593 (Australian Securities and Investment Commission, September 2018) <www.asic.gov.au/media/4871341/rep593-published-20-september-2018.pdf> accessed 5 July 2018; Climate Change Risk Disclosure: A Practical Guide to Reporting against ASX Corporate Governance Council's Corporate Governance Principles and Recommendations (Governance Institute of Australia, February 2020) <www.asx.com.au/documents/asx-compliance/gia-climatechange-guide.pdf $>$ accessed 5 July 2021; 'Understanding and Managing the Financial Risks of Climate Change' Letter from Australian Prudential Regulatory Authority, 24 February 2020 <www.apra.gov.au/sites/default/files/2020-02/Understanding\%20and\%20managing\%20the\% 20financial\%20risks\%20of\%20climate\%20change.pdf $>$ accessed 5 July 2021; Final Report: Recommendations of the Task Force on Climate-Related Financial Disclosures (Task Force on 
ways, including by focusing company attention on the financial risks posed by climate change and the development of responsive strategy, ${ }^{242}$ encouraging investors to 'green' their portfolios ${ }^{243}$ and informing investor engagement. ${ }^{244}$ Climate change disclosure litigation has already met with success in Australia. ${ }^{245}$ The relevant issue here is the role of class actions, about which several observations can be made.

First, and unusually, ${ }^{246}$ this case has been brought under the 'old' representative proceeding provisions ${ }^{247}$ rather than Part IVA (as was the Sharma Class Action), ${ }^{248}$ possibly to avoid the procedural challenges which attend Part IVA, such as requirements to give notice and for any settlement to be approved by the Court. ${ }^{249}$ Concerns have been raised about whether the case is properly brought as a class action, and why Part IVA was not used. ${ }^{250}$ The defendant has complained about the pleading, and orders have been made programming a strike-out application which has been listed for hearing in July $2021 .{ }^{251}$

Climate-related Financial Disclosures, Financial Stability Board, June 2017) 74; Noel Hutley and Sebastian Hartford Davis, Climate Change and Directors' Duties, Supplementary Memorandum of Opinion (26 March 2019) 34, 3-4 ([6]-[7]).

242. Peel et al (n 8) 10 ([31]-[33]).

243. Jacqueline Peel and Rebekkah Markey-Towler, 'Climate Change Risk and Sovereign Bond Investments: The Case of O'Donnell v Commonwealth of Australia' (2020) 14(3) Carbon \& Climate Law Review 177, 186.

244. Peel et al (n 8) 10 ([31]-[33]).

245. In 2017 an individual proceeding was brought in respect of alleged non-disclosure of climate risks in CBA's annual report, and discontinued shortly thereafter when the bank acknowledge climate change risks in its subsequent report and agreed to undertake climate change analysis to assess the risk: Abrahams v Commonwealth Bank of Australia, VID879/2017, Concise Statement (Federal Court of Australia, 8 August 2017); Gareth Hutchens, 'Commonwealth Bank Shareholders Drop Suit over Nondisclosure of Climate Risks', The Guardian (online, 21 September 2017) <www.theguardian.com/australia-news/2017/sep/21/commonwealth-bankshareholders-drop-suit-over-non-disclosure-of-climate-risks> accessed 5 July 2021. In 2018, an individual plaintiff alleged that the defendant superannuation trustee (Rest) failed to provide information related to climate change business risks and any plans to address those risks, and failed to act with care, skill and diligence when investing for the plaintiff and 'failed to act in his best interests, by not properly considering the risks climate change poses to the fund's investments'. The case settled, with Rest making a number of significant commitments around disclosure and investment strategy, including to strive to achieve a net zero carbon footprint for the fund by 2050: 'McVeigh v Rest', Equity Generation Lawyers <https://equitygenerationlaw yers.com/cases/mcveigh-v-rest/> accessed 5 July 2021; Paul Hayes, 'Media Release: Statement from Rest' (2 November 2020) <https://equitygenerationlawyers.com/wp/wp-content/uploads/ 2020/11/Statement-from-Rest-2-November-2020.pdf> accessed 5 July 2021.

246. See however Arthur v Northern Territory (No 2) [2020] FCA 215 on behalf of detainees at youth detention centres in the Northern Territory.

247. Federal Court Rules (n 211) r 9.21.

248. Concise Statement in Sharma v Minister for the Environment (Federal Court of Australia, VID607/2020, 8 September 2020), [1].

249. These requirements may however be applied to Division 9.2 cases: Arthur v Northern Territory (No 2) (n 245) [79].

250. Miklos Bolza, 'Climate Change Lawsuit "Hopelessly Defective", Court Told', Lawyerly (online, 10 November 2020) <www.lawyerly.com.au/government-will-push-to-strikeout-hopelessly-defective-climate-change-lawsuit/> accessed 30 November 2020.

251. Order of Justice Murphy in O'Donnell v Commonwealth of Australia (Federal Court of Australia, VID482/2020, 17 February 2021); Order of Justice Murphy in O'Donnell v Commonwealth of Australia (Federal Court of Australia, VID482/2020, 8 April 2021). 
Secondly, the plaintiff seeks declaratory and injunctive relief only. ${ }^{252}$ This enables the plaintiff and group members to assert they have the 'same interest' in the proceeding as required under the 'old' provisions, ${ }^{253}$ and avoids the need to adduce expensive evidence as to causation and loss. ${ }^{254}$ It is permissible to bring a class action for declaratory and injunctive relief to restrain the contravention of a statutory provision in circumstances where one declaration or injunction might suffice to protect the public interest, in keeping with the 'access to justice' purpose of Pt IVA and to avoid 'a multiplicity of proceedings by individuals seeking to enforce public duties' ${ }^{255}$ The question is whether it is a good idea. On one view, bringing the claims as a class action enables participation by those aggrieved by a lack of disclosure of climate change risk, and is a potent tool for promoting public awareness ${ }^{256}$ and environmental democracy. On another, the use of class actions as a public communications exercise is unlikely to enhance the integrity of the civil justice system, and does not enable claims to be determined more efficiently than had they been brought individually (because put simply, one claim would have sufficed).

Likewise in the Sharma Class Action, only injunctive and declaratory relief are sought and an individual claim may have been as effective, from a practical perspective, as a class action, given it seems unlikely there would arise a need for children other than the eight plaintiffs to enforce the Minister's duty in respect of the Extension Project. The Court's determination that the action should proceed as a representative action on behalf of Australian children focused on the permissibility of it so proceeding under the 'old' provisions in circumstances where the 'same interest' requirement was satisfied and in the absence of any discretionary consideration requiring it being discontinued. ${ }^{257}$ Given the reliance upon those provisions, which are not accompanied by procedural requirements relating for example to opt out, and that minimal time appears to have been devoted to arguing class action issues, there was perhaps no practical detriment to the plaintiffs and group members in the matter being brought and conducted as a representative proceeding, and an advantage in terms of participation. It does seem somewhat incongruent however that where the interest sought to be vindicated by group members is the same, the provisions of Part IVA can be so easily sidestepped.

Careful consideration will need to be given as to whether particular actions should be brought as class actions. Whilst public engagement is an important feature

252. 'O'Donnell v Commonwealth' (n 244).

253. Federal Court Rules (n 211) r 9.21.

254. For a discussion of the evidentiary hurdles to proving causation and damage in shareholder class actions, see Jonathan Beach, 'Structural and Forensic Developments in Securities Litigation' (Federal Court of Australia, 2016) <www.fedcourt.gov.au/digital-law-library/ judges-speeches/justice-beach/beach-j-20160629> accessed 5 July 2021.

255. See, eg, Bray v F Hoffman-La Roche Ltd (2003) 130 FCR 317, [118]-[119].

256. Peel and Markey-Towler (n 239) 186; Isabella Kwai, 'Australian Student Sues Government Over Financial Risks of Climate Change', The New York Times (online, 23 July 2020) <www. nytimes.com/2020/07/23/world/australia/lawsuit-climate-change-bonds.html> accessed 5 July 2021; Martin Ollman, 'Student Files Climate Change Lawsuit against Australian Government', BBC News (online, 22 July 2020) <www.bbc.com/news/world-australia-53497949> accessed 5 July 2021; Matthew Burgess, 'Law Student Sues Australia over Climate Risk in Government Bonds', Al Jazeera (online, 9 November 2020) <www.aljazeera.com/economy/2020/11/9/ woman-23-sues-australian-over-climate-risk-in-govt-bonds> accessed 5 July 2021.

257. Sharma v Minister for the Environment (No 2) n 179 [11], [23]. 
of environmental democracy, and '[i]magination is needed to tackle the climate emergency, ${ }^{258}$ actions which are not needed to be brought as class actions may waste courts' and parties' resources (due to the need to comply with class action procedural requirements for example), with little environmental benefit. Thus whilst it seems likely that actions alleging breach of directors' duties for failing to address climate risk are 'only a matter of time', ${ }^{259}$ such actions may be more effectively conducted as individual actions seeking broad relief (such as injunctions and declarations which have wider public benefit) where damages are not sought.

\section{CONCLUDING REMARKS}

Class actions are obviously not a panacea for all environmental problems. Environmental class actions are reactive, complex, not always available, and not always successful. They involve high stakes, and at least where they proceed to judgment, tend to be celebrated successes or unmitigated disasters. Where they settle, group members are not always satisfied, and environmental remediation may not be prioritized. Whilst environmental class actions may be followed by policy or regulatory changes, it seems unlikely those responses can be attributed solely to class actions.

The foregoing analysis has shown however that meritorious environmental class actions have been appropriately commenced in steady but modest numbers and closely supervised by the courts. Further, they have delivered substantial compensation to claimants in diverse environmental damage, facilitated participatory democracy, determined rights and responsibilities and enhanced accountability.

The effective contribution of class actions to environmental governance is likely to require ongoing examination of their role and impact. In the meantime, review of the environmental class actions brought in Australia to date shows that they have provided a significant and valuable contribution to environmental governance.

258. Brian Preston, 'Legal Imagination and Climate Litigation - (2020) 35(1) AE 2' (2020) 35(1) Australian Environment Review 2.

259. Noel Hutley and Sebastian Hartford-Davis, Climate Change and Directors' Duties, Memorandum of Opinion (7 October 2016) <https://cpd.org.au/wp-content/uploads/2016/10/LegalOpinion-on-Climate-Change-and-Directors-Duties.pdf $>$ accessed 5 July 2021; Hutley and Hartford Davis (n 237) 2 [2]. 
Schedule 1

\begin{tabular}{|c|c|c|c|c|}
\hline Proceeding & Jurisdiction & Bushfire & Claims & Status \\
\hline $\begin{array}{l}\text { Perry } v \\
\text { Powercor } \\
\text { Australia Ltd }\end{array}$ & VSC & $\begin{array}{l}\text { Coleraine, Victoria, } \\
\text { February } 2009\end{array}$ & $\begin{array}{l}\text { Property loss } \\
\text { or damage }\end{array}$ & $\begin{array}{l}\text { Settlement of } 55 \% \text { of } \\
\text { claimants' losses, } \\
\text { plus penalty interest } \\
\text { plus party/party } \\
\text { costs }^{260}\end{array}$ \\
\hline $\begin{array}{l}\text { Matthews } v \\
\text { SPI Electricity } \\
\text { Pty Ltd }\end{array}$ & VSC & $\begin{array}{l}\text { Kilmore / East- } \\
\text { Kinglake, Victoria, } \\
\text { February } 2009\end{array}$ & $\begin{array}{l}\text { Personal } \\
\text { injury; } \\
\text { property loss } \\
\text { or damage; } \\
\text { economic loss }\end{array}$ & $\begin{array}{l}\text { Settlement for } \sim \\
\$ 495 \mathrm{~m} \text { inclusive of } \\
\text { costs }^{261}\end{array}$ \\
\hline $\begin{array}{l}\text { Thomas } v \\
\text { Powercor } \\
\text { Australia Ltd }\end{array}$ & VSC & $\begin{array}{l}\text { Horsham, Victoria, } \\
\text { February } 2009\end{array}$ & $\begin{array}{l}\text { Property loss } \\
\text { or damage }\end{array}$ & $\begin{array}{l}\text { Settlement of } 55 \% \text { of } \\
\text { claimants' losses, } \\
\text { plus penalty interest } \\
\text { plus party/party } \\
\text { costs }^{262}\end{array}$ \\
\hline $\begin{array}{l}\text { Mercieca v } \\
\text { SPI Electricity } \\
\text { Pty Ltd }\end{array}$ & VSC & $\begin{array}{l}\text { Beechworth, } \\
\text { Victoria, } \\
\text { February } 2009\end{array}$ & $\begin{array}{l}\text { Property loss } \\
\text { or damage }\end{array}$ & $\begin{array}{l}\text { Settlement for } \$ 32.85 \\
\text { million inclusive of } \\
\text { costs with a } \$ 2 \mathrm{~m} \text { top } \\
\text { up if Settlement Sum } \\
<43 \% \text { of assessed } \\
\operatorname{losses}^{263}\end{array}$ \\
\hline $\begin{array}{l}\text { Rowe v AusNet } \\
\text { Electricity } \\
\text { Services Pty } \\
\text { Ltd }\end{array}$ & VSC & $\begin{array}{l}\text { Murrindindi, } \\
\text { Victoria, } \\
\text { February } 2009\end{array}$ & $\begin{array}{l}\text { Personal } \\
\text { injury; } \\
\text { property loss } \\
\text { or damage; } \\
\text { economic loss }\end{array}$ & $\begin{array}{l}\text { Settlement for } \$ 300 \mathrm{~m} \\
\text { inclusive of costs } 264\end{array}$ \\
\hline $\begin{array}{l}\text { Ramsay v } \\
\text { AusNet } \\
\text { Electricity } \\
\text { Services Pty } \\
\text { Ltd }\end{array}$ & VSC & $\begin{array}{l}\text { Jack River, } \\
\text { Victoria, } \\
\text { February } 2009\end{array}$ & $\begin{array}{l}\text { Personal } \\
\text { injury; } \\
\text { property } \\
\text { loss or } \\
\text { damage; } \\
\text { economic loss }\end{array}$ & $\begin{array}{l}\text { Settlement for } \\
\$ 10.5 \mathrm{~m} \text { inclusive of } \\
\text { costs }^{265}\end{array}$ \\
\hline $\begin{array}{l}\text { Williams } v \\
\text { AusNet Electricity } \\
\text { Services Pty } \\
\text { Ltd }\end{array}$ & VSC & $\begin{array}{l}\text { Mickleham, } \\
\text { Victoria, } \\
\text { February } 2014\end{array}$ & $\begin{array}{l}\text { Personal } \\
\text { injury; } \\
\text { property loss } \\
\text { or damage; } \\
\text { economic loss }\end{array}$ & $\begin{array}{l}\text { Settlement for } \$ 16 \mathrm{~m} \\
\text { inclusive of costs }\end{array}$ \\
\hline
\end{tabular}

260. Perry v Powercor Australia Ltd (n 91) [5].

261. Matthews v AusNet Electricity Services Pty Ltd (n 91).

262. Thomas $v$ Powercor Australia Ltd (n 91) [18].

263. Mercieca v SPI Electricity Pty Ltd (n 91) [21].

264. Rowe v Ausnet Electricity Services Pty Ltd (n 91).

265. Ramsay v AusNet Electricity Services Pty Ltd (n 91).

266. Williams v Ausnet Electricity Services Pty Ltd (n 91). 
Schedule 1 (continued)

\begin{tabular}{|c|c|c|c|c|}
\hline Proceeding & Jurisdiction & Bushfire & Claims & Status \\
\hline $\begin{array}{l}\text { Johnston v } \\
\text { Endeavour } \\
\text { Energy }\end{array}$ & NSWSC & $\begin{array}{l}\text { Springwood, NSW, } \\
\text { October } 2013\end{array}$ & $\begin{array}{l}\text { Personal } \\
\text { injury; } \\
\text { property loss } \\
\text { or damage }\end{array}$ & $\begin{array}{l}\text { Settlement for } \$ 18 \mathrm{~m} \\
\text { inclusive of costs }\end{array}$ \\
\hline $\begin{array}{l}\text { Herridge v } \\
\text { Electricity } \\
\text { Networks } \\
\text { Corp }\end{array}$ & WASC & $\begin{array}{l}\text { Parkerville, WA, } \\
\text { January } 2014\end{array}$ & $\begin{array}{l}\text { Property loss } \\
\text { or damage; } \\
\text { economic } \\
\text { loss }\end{array}$ & $\begin{array}{l}\text { Judgment in common } \\
\text { issues trial delivered } \\
\text { on } 27 \text { March } 2019 \text { in } \\
\text { favour of plaintiffs as } \\
\text { against second and } \\
\text { third defendants }\end{array}$ \\
\hline $\begin{array}{l}\text { Eades v } \\
\text { Endeavour } \\
\text { Energy }\end{array}$ & NSWSC & $\begin{array}{l}\text { Mount Victoria, } \\
\text { NSW, October } 2013\end{array}$ & $\begin{array}{l}\text { Personal } \\
\text { injury; } \\
\text { property } \\
\text { loss or } \\
\text { damage; } \\
\text { economic loss }\end{array}$ & $\begin{array}{l}\text { Settlement for } \\
\$ 2,680,000 \text { inclusive } \\
\text { of costs, }{ }^{269} \text { reportedly } \\
\text { approved in October } \\
\text { and November } \\
2018^{270}\end{array}$ \\
\hline $\begin{array}{l}\text { Weber v Greater } \\
\text { Hume Shire } \\
\text { Council }\end{array}$ & NSWSC & $\begin{array}{l}\text { Bushfire in Walla } \\
\text { Walla, NSW, } \\
\text { December } 2009 \\
\text { commencing in } \\
\text { rubbish tip }\end{array}$ & $\begin{array}{l}\text { Personal } \\
\text { injury; } \\
\text { property loss } \\
\text { or damage }\end{array}$ & $\begin{array}{l}\text { Settlement for } \$ 16 \mathrm{~m} \\
\text { provisionally } \\
\text { approved on } 10 \\
\text { March } 2020^{271}\end{array}$ \\
\hline $\begin{array}{l}\text { Schmid v } \\
\text { Skimming }\end{array}$ & VSC & $\begin{array}{l}\text { Bushfire in } \\
\text { Scotsburn, } \\
\text { Victoria in } \\
\text { December } 2015\end{array}$ & $\begin{array}{l}\text { Personal } \\
\text { injury; } \\
\text { property loss } \\
\text { or damage }\end{array}$ & $\begin{array}{l}\text { Settlement for } \\
\$ 10.5 \mathrm{~m} \text { inclusive of } \\
\text { costs }^{272}\end{array}$ \\
\hline $\begin{array}{l}\text { Ritchie v } \\
\text { Advanced } \\
\text { Plumbing and } \\
\text { Drains Pty Ltd }\end{array}$ & NSWSC & $\begin{array}{l}\text { Carwoola NSW, } \\
\text { February } 2017\end{array}$ & & Ongoing \\
\hline
\end{tabular}

(continued)

267. Johnston v Endeavour Energy (n 91) 9.

268. Herridge v Electricity Networks Corporation (No 4) (n 91).

269. Eades v Endeavour Energy 2015/310264, Notice of Settlement and Proposed Distribution of Settlement Fund.

270. Cat Fredenburgh, 'Class Members Get Nothing in \$2.6M Bushfire Class Action Settlement', Lawyerly (online, 13 November 2018) <www.lawyerly.com.au/class-members-get-nothing-in-26m-bushfire-class-action-settlement/> accessed 4 November 2020.

271. Order in Weber v Greater Hume Shire Council (Supreme Court of New South Wales, 2015/368036, 10 March 2020).

272. Schmid v Skimming (n 198). 
40 Asia Pacific Journal of Environmental Law, Vol. 24 No. 1

Schedule 1 (continued)

\begin{tabular}{|c|c|c|c|c|}
\hline Proceeding & Jurisdiction & Bushfire & Claims & Status \\
\hline $\begin{array}{l}\text { Kuhn } v \text { Infigen } \\
\text { Energy Limited }\end{array}$ & NSWSC & $\begin{array}{l}\text { Currandooley } \\
\text { Road, Lake } \\
\text { George, NSW, } \\
\text { January } 2017\end{array}$ & $\begin{array}{l}\text { Personal } \\
\text { injury; } \\
\text { property loss } \\
\text { or damage }\end{array}$ & $\begin{array}{l}\text { Settlement on } \\
\text { confidential terms }\end{array}$ \\
\hline $\begin{array}{l}\text { Francis } v \\
\text { Powercor } \\
\text { Australia Ltd }\end{array}$ & VSC & $\begin{array}{l}\text { Garvoc, Vic, } \\
\text { March } 2018\end{array}$ & $\begin{array}{l}\text { Personal } \\
\text { injury; } \\
\text { property loss } \\
\text { or damage }\end{array}$ & Settlement of $\$ 5 \mathrm{~m}^{274}$ \\
\hline $\begin{array}{l}\text { Lenehan v } \\
\text { Powercor } \\
\text { Australia Ltd }\end{array}$ & VSC & $\begin{array}{l}\text { Terang, Vic, } \\
\text { March } 2018\end{array}$ & $\begin{array}{l}\text { Personal } \\
\text { injury; } \\
\text { property loss } \\
\text { or damage }\end{array}$ & $\begin{array}{l}\text { Settlement of } \\
\$ 17.5 \mathrm{~m}^{275}\end{array}$ \\
\hline $\begin{array}{l}\text { Hawker v } \\
\text { Powercor } \\
\text { Australia Ltd }\end{array}$ & VSC & $\begin{array}{l}\text { Gnotuk, Vic, } \\
\text { March } 2018\end{array}$ & $\begin{array}{l}\text { Personal } \\
\text { injury; } \\
\text { property loss } \\
\text { or damage }\end{array}$ & $\begin{array}{l}\text { Settlement on basis } \\
\text { each party bear its } \\
\text { own costs }\end{array}$ \\
\hline $\begin{array}{l}\text { Block v } \\
\text { Powercor } \\
\text { Australia Ltd }\end{array}$ & VSC & $\begin{array}{l}\text { Gazette, Vic, } \\
\text { March } 2018\end{array}$ & $\begin{array}{l}\text { Personal } \\
\text { injury; } \\
\text { property loss } \\
\text { or damage }\end{array}$ & $\begin{array}{l}\text { Proceeding summa- } \\
\text { rily dismissed }\end{array}$ \\
\hline $\begin{array}{l}\text { Prestage v } \\
\text { Barrett }\end{array}$ & TSC & $\begin{array}{l}\text { Dunalley, } \\
\text { Tasmania, } 2013\end{array}$ & & $\begin{array}{l}\text { Proceeding } \\
\text { commenced in 2018, } \\
\text { judgment pending }\end{array}$ \\
\hline \multirow[t]{2}{*}{$\begin{array}{l}\text { Cardosa v } \\
\text { SA Power } \\
\text { Networks }\end{array}$} & SASC & $\begin{array}{l}\text { Yorketowne, SA, } \\
\text { November } 2019\end{array}$ & $\begin{array}{l}\text { Personal } \\
\text { injury; } \\
\text { property loss } \\
\text { or damage }\end{array}$ & Ongoing \\
\hline & SASC & $\begin{array}{l}\text { Cudlee Creek, SA, } \\
\text { December } 2019\end{array}$ & & $\begin{array}{l}\text { Issued, } 20 \text { March } \\
2021^{278}\end{array}$ \\
\hline
\end{tabular}

273. Kuhn v Infigen Energy Ltd (2017/131194), Notice of Proposed Settlement; NSW Department of Justice, 'Completed Class Action Cases' (12 May 2015) <www.supremecourt.justice.nsw.gov. au:443/Pages/sco2_classaction/sco2_class_actions_completed.aspx> accessed 5 July 2021.

274. Francis v Powercor Australia (SCI201801113), Orders (Supreme Court of Victoria, 20 December 2019).

275. Lenehan v Powercor Australia Ltd (No 2) (n 91).

276. Hawker v Powercor Australia Ltd (n 91).

277. Block v Powercor Australia Ltd (n 213).

278. '2019 Cudlee Creek Bushfire', Maddens Lawyers <https://maddenslawyers.com.au/ 2019cudleecreekbushfire/> accessed 5 July 2021. 